\title{
COMMENTARY
}

\section{ANTIDISCRIMINATION AND ACCOMMODATION}

\author{
Christine Jolls
}

\section{TABLE OF CONTENTS}

INTRODUCTION

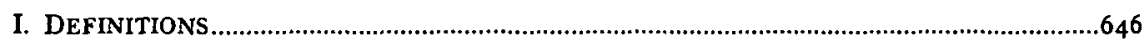

II. ANTIDISCRIMINATION AS ACCOMMODATION - CASES OF EQUIVALENCE .......................65 I

A. Disparate Impact Liability as Accommodation ..............................................................652

$B$. Implications for the Relationship Between Antidiscrimination

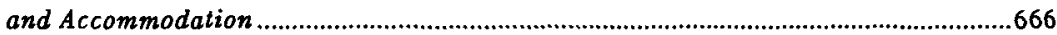

C. Implications for Section 5 of the Fourteenth Amendment.........................................672

III. ADDITIONAL PARALlELS BETWEEN ANTIDISCRIMINATION

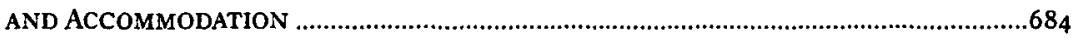

A. Customer/Coworker Discrimination and Rational Statistical

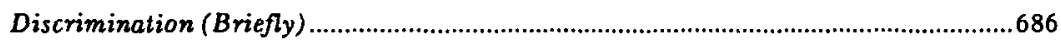

B. Effects of Antidiscrimination and Accommodation on Wages

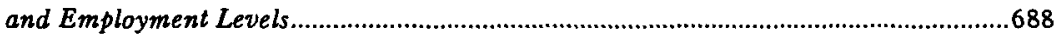

C. Beyond Cost

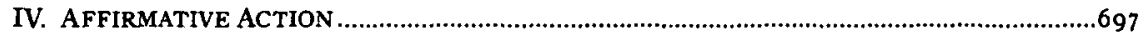

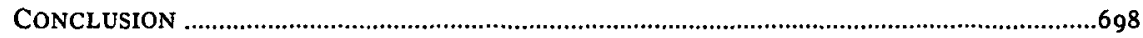




\title{
COMMENTARY
}

\section{ANTIDISCRIMINATION AND ACCOMMODATION}

\author{
Christine Jolls*
}

\section{INTRODUCTION}

The canonical idea of "antidiscrimination" in the United States condemns the differential treatment of otherwise similarly situated individuals on the basis of race, sex, national origin, or other protected characteristics. ${ }^{1}$ Starting from this perspective, legal requirements that actors take affirmative steps to "accommodate" the special, distinctive needs of particular groups, such as individuals with disabilities, by providing additional benefits or allowances to them strike many observers as fundamentally distinct from, broader than, and often less legitimate than legal requirements within the canonical "antidiscrimination" category. On this ground, observers sharply contrast Title VII of the Civil Rights Act of $1964^{2}$ and other older civil rights enactments, which are said to be "real anti-discrimination law[s]," with the Americans with Disabilities Act of 1990 (ADA) ${ }^{4}$ and the Family and Medical Leave Act of 1993 (FMLA), said to be "accommodation" laws. ${ }^{6}$ On

* Professor of Law, Harvard Law School. For helpful comments on this work, either in its present form or in prior incarnations, I thank Samuel Bagenstos, Ruth Colker, John Donohue, Richard Fallon, Barbara Fried, Michael Harper, Samuel Issacharoff, Howell Jackson, Louis Kaplow, Daniel Meltzer, Martha Minow, Eric Posner, Richard Posner, Todd Rakoff, Eric Rakowski, Diane Ring, Margo Schlanger, Vicki Schultz, Roger Tufts, Steven Willborn, Stephen Williams, and especially David Charny, Duncan Kennedy, and Cass Sunstein, whose detailed reactions to earlier versions of this work convinced me to reformulate it in the form it now takes. I also acknowledge help from workshop participants at Georgetown University Law Center, Harvard Law School, New York University School of Law, Princeton University, Stanford Law School, the University of California at Berkeley School of Law, the University of Virginia School of Law, and Yale Law School. For extraordinary research assistance, I thank Dan Geyser, Ana Reyes, Gil Seinfeld, and Daniel Volchok.

1 See, e.g., Robert Post, Prejudicial Appearances: The Logic of American Antidiscrimination Law, 88 CAL. L. REV. I, 9-12 (2000).

${ }_{2} 42$ U.S.C. $\$ \S 2000 \mathrm{e}-2000 \mathrm{e}-\mathrm{I} 7$ (1994 \& Supp. I 1995).

3 Erickson v. Bd. of Governors of State Colls. and Univs. for Northeastern Ill. Univ., 207 F.3d 945, 951 (7th Cir. 2000) (the Age Discrimination in Employment Act of 1967 is a "real antidiscrimination law"), cert. denied, I2 I S. Ct. II87 (2001).

$44^{2}$ U.S.C. $\$$ 12,101-12,2 13 (1994 \& Supp. II 1996).

529 U.S.C. $\$ \S 2601-2654$ (1994 \& Supp. III 1 997).

6 See sources cited infra note 16 . 
these observers' view, "antidiscrimination" focuses on "equal" treatment, while "accommodation" focuses on "special" treatment."

This notion of the relationship between antidiscrimination and accommodation has doctrinal as well as normative and analytic dimensions. At the level of doctrine, the relationship between the two categories plays an important role in determining Congress's power to enact various federal employment laws under Section 5 of the Fourteenth Amendment. Congress must rely on Section 5 if it is authorizing private actors to sue state governments for money damages. ${ }^{8}$ Section 5 empowers Congress to "enforce, by appropriate legislation," the substantive provisions of the Fourteenth Amendment, including the antidiscrimination requirement of the Equal Protection Clause. However, if the concept of accommodation is fundamentally distinct from the sort of legislation that validly enforces the antidiscrimination requirement of the Equal Protection Clause, then Congress's power under Section 5 presumably does not extend to accommodation requirements.

A striking recent illustration of just this form of reasoning is Judge Frank Easterbrook's opinion in Erickson v. Board of Governors, ${ }^{10}$ holding, as the Supreme Court subsequently did in Board of Trustees of the University of Alabama $v$. Garrett, ${ }^{11}$ that Title I of the ADA is not within Congress's power under Section 5. "[T]he ADA," Judge Easterbrook wrote, "requires employers to consider and to accommodate disabilities, and in the process extends beyond the antidiscrimination principle"; thus the ADA cannot be considered proper "'enforcement' of the Fourteenth Amendment." 12 The court in Sims $v$. University of Cincinnati ${ }^{13}$ relied on the same argument in support of its conclusion that the FMLA's requirement that employees be allowed to take medical leave under specified circumstances is not within Congress's Section 5 power. ${ }^{14}$

The relationship between antidiscrimination and accommodation is of course a very large topic. In one form or another, it has been the subject of an old and expansive debate spanning several decades, dating back at least to the early feminist argument that antidiscrimination

7 See, e.g., Sherwin Rosen, Disability Accommodation and the Labor Market, in DISABILITY AND WORK 18, 2 I (Carolyn L. Weaver ed., 1991).

8 E.g., Kimel v. Fla. Bd. of Regents, 528 U.S. 62, 80 (2000).

9 U.S. ConST. amend. XIV, $\$ 5$.

10207 F.3d 945 (7th Cir. 2000), cert. denied, 12 I S. Ct. I 187 (2001).

11 I 2 I S. Ct. 955 (200I).

12 Erickson, 207 F.3d at 949.

132 r9 F.3d 559 (6th Cir. 2000).

14 Id. at 565. 
includes an accommodation component related to pregnancy. ${ }^{15} \mathrm{My}$ goal here is certainly not to resolve every aspect of that large debate. Instead it is to fill in two important pieces that have been missing from the discussion.

The first is that, in a broader respect than has generally been appreciated, some aspects of antidiscrimination law - in particular its disparate impact branch - are in fact requirements of accommodation. In such instances it is hard to resist the conclusion that antidiscrimination and accommodation are overlapping rather than fundamentally distinct categories, despite the frequent claims of commentators to the contrary. ${ }^{16}$ The overlap between the two categories, I suggest, also sheds light on the question of Congress's power under Section 5 of the Fourteenth Amendment to enact laws (such as the FMLA) that expressly mandate the provision of particular employment benefits directed toward specific groups of employees. All of these arguments are developed in Part II below.

The second missing piece in the debate is that even those aspects of antidiscrimination law that are not in fact accommodation requirements in the sense just described are similar to accommodation requirements in respects that have not previously been understood. The starting point for this argument - and this is a point that has been recognized previously ${ }^{17}$ - is the operation of antidiscrimination law when an employer's reluctance to employ members of a particular group stems from dislike of this group by customers or coworkers or from the employer's statistically accurate generalizations about group members. In these situations antidiscrimination law fairly obviously operates to require employers to incur undeniable financial costs associated with employing the disfavored group of employees - and thus in a real sense to "accommodate" these employees. But, as Part III describes, the parallel between antidiscrimination and accommodation in their imposition of such costs on employers is broader and embraces additional aspects of antidiscrimination law as well. This parallel

15 See, e.g., Herma Hill Kay, Equality and Difference: The Case of Pregnancy, I BERKELEY WOMEN'S L.J. I, 26-28 (I985); Reva B. Siegel, Note, Employment Equality Under the Pregnancy Discrimination Act of 1978, 94 YALE L.J. 929, 929-30 (I985).

16 See, e.g., Samuel Issacharoff \& Justin Nelson, Discrimination with a Difference: Can Employment Discrimination Law Accommodate the Americans with Disabilities Act?, 79 N.C. L. REV. 307, 310-II \& nn.21-22 (2001); Pamela S. Karlan \& George Rutherglen, Disabilities, Discrimination, and Reasonable Accommodation, 46 DUKE L.J. I, 2-4, 9 (1996); Linda Hamilton Krieger, Foreword-Backlash Against the ADA: Interdisciplinary Perspectives and Implications for Social Justice Strategies, 2 I BERKELEY J. EMP. \& LAB. L. I, 3-4 (2000); Rosen, supra note 7, at 2I; Stewart J. Schwab \& Steven L. Willborn, Reasonable Accommodation of Workplace Disabilities 1-3, 28-29, 64 (Mar. 2I, 2000) (unpublished manuscript, on file with the Harvard Law School Library).

17 E.g., Samuel R. Bagenstos, Subordination, Stigma, and "Disability", 86 VA. L. REV. 397, $456-57 \&$ n.223 (2000). 
complements other, non-cost arguments in the existing literature for recognizing the conceptual and analytic commonality of antidiscrimination and accommodation. ${ }^{18}$

Part III's analysis, in addition to suggesting that antidiscrimination shares such previously unrecognized similarities to accommodation, is of independent interest in showing how antidiscrimination law may be analyzed using a supply and demand framework drawn from economics. The analysis I offer in this commentary builds upon and extends John Donohue's well-known work in this area. ${ }^{19}$

Part IV briefly relates the discussion of antidiscrimination and accommodation offered here to the controversy surrounding affirmative action. Part I introduces the topic by defining "antidiscrimination" and "accommodation" more precisely.

\section{DEFINITIONS}

Throughout this commentary, "antidiscrimination" is used to refer to the constitutional and statutory prohibitions on race, sex, and national origin discrimination contained in the Equal Protection Clause of the Fourteenth Amendment and Title VII of the Civil Rights Act of I 964 . Of course, both of these provisions have been subject to judicial interpretation, and so $I$ include in the definition of antidiscrimination the judicial gloss that exists on the two sources of law. It is clear as well that these two provisions are not coterminous; Title VII sweeps more broadly in important respects to be described shortly.

Both the Equal Protection Clause and Title VII prohibit discrimination on the basis of traits other than race, sex, and national origin (the traits mentioned just above) as well. Distinctions drawn by states (as opposed to the federal government) on the basis of alienage generally violate the Equal Protection Clause; however, Title VII permits them. ${ }^{20}$ By contrast, distinctions based on religion generally violate Title VII, ${ }^{21}$ while under the Constitution they are usually scrutinized not under the Equal Protection Clause but rather under the Free Exercise Clause of the First Amendment. ${ }^{22}$ Because of the differences in

18 See, e.g., Kay, supra note I5, at 26-28; Martha Minow, The Supreme Court, 1086 TermForeword: Justice Engendered, IOI HARV. L. REV. 10, 38-45 (1987); Cass R. Sunstein, Why Markets Don't Stop Discrimination, Soc. PHIL. \& POL'Y, Spring I99 I, at 22, 34-35 (I99r).

19 John J. Donohue III, Is Title VII Efficient?, 134 U. PA. L. REV. I4I I, 14I5-30 (I986).

$20 \mathrm{See}$ Graham v. Richardson, 403 U.S. 365, 372 (I97I) ("[C]lassifications based on alienage, like those based on nationality or race, are inherently suspect and subject to close judicial scrutiny" under the Equal Protection Clause); Espinoza v. Farah Mfg. Co., 4I4 U.S. 86, 95 (1973) ("[N]othing in [Title VII] makes it illegal to discriminate on the basis of . . . alienage.").

2142 U.S.C. \& $20000-2$ (a) (1994).

22 See Goldman v. Weinberger, 475 U.S. 503, 506-10 (1986) (Free Exercise Clause challenge). Of course, such distinctions might also violate the Equal Protection Clause. Ohio Adult Parole Auth. v. Woodard, 523 U.S. 272, 292 ( 1998 ) (Stevens, J., concurring in part and dissenting in part). 
the scope of the Equal Protection Clause and Title VII insofar as their application to certain groups is concerned, I limit my discussion here to the traits of race, sex, and national origin, which are central applications of both of these provisions.

While both the Equal Protection Clause and Title VII apply to discrimination on the basis of sex, such discrimination is defined more expansively under Title VII than under the Constitution. Discrimination on the basis of sex includes discrimination on the basis of pregnancy under Title VII, but not under the Equal Protection Clause. ${ }^{23}$ Again, my definition of antidiscrimination here embraces everything that is reached by either source of law.

To see the broader respect in which Title VII sweeps more expansively than the Equal Protection Clause, it is important to distinguish between two forms of antidiscrimination liability. "Disparate treatment" liability arises when employers are demonstrated to have intentionally disfavored workers with particular traits (race, sex, or national origin as relevant here). ${ }^{24}$ This can occur when employers facially single these employees out for worse treatment (for instance, an express statement that "no blacks need apply") and also when employers, while less direct in their actions, nonetheless can be shown to have disfavored employees with particular traits on account of those traits (as, for instance, when an employer rarely or never hires black applicants and is observed to have made inappropriate racial comments). "Disparate impact" liability, by contrast, occurs when employers rely on facially neutral practices that cause disproportionate harm to a particular group of employees and are not justified by job relatedness and business necessity. ${ }^{25}$ Behavior in this second category may result from an underlying intent to disfavor a particular group, as discussed more fully in Part II below, but such intent need not be demonstrated in order to establish the employer's liability under the disparate impact branch of antidiscrimination law. Title VII authorizes both forms of antidiscrimination liability, but only disparate treatment discrimination gives rise to heightened scrutiny under the Equal Protection Clause. ${ }^{26}$

Because the presence or absence of demonstrated intent is what distinguishes disparate treatment from disparate impact, the question of what constitutes "intent" for this purpose is obviously an important one. Although, as described more fully in section III.C below, some scholars have suggested broad conceptions of intent - under which, for instance, the failure to make buildings accessible to individuals

23 See 42 U.S.C. $\$ 2000$ (k) (1994) (Title VII); Geduldig v. Aiello, 4 I 7 U.S. $484,496-97 \&$ n.2o (I974) (Equal Protection Clause).

24 E.g., Int'l Bhd. of Teamsters v. United States, 43r U.S. 324, 335 n.I 5 (1977).

25 E.g., id.

26 Washington v. Davis, 426 U.S. 229, $238-48$ (1976). 
with disabilities because of a lack of concern over those individuals' particular circumstances may be termed a form of intentional differential treatment - such broad conceptions of intent have not been reflected in antidiscrimination doctrine. As the Supreme Court famously put it in Personnel Administrator $v$. Feeney, ${ }^{27}$ addressing the standard of intent under the Equal Protection Clause, "'Discriminatory purpose' ... implies more than intent as volition or intent as awareness of consequences. It implies that the decisionmaker . . . selected or reaffirmed a particular course of action at least in part 'because of,' not merely 'in spite of,' its adverse effects upon an identifiable group."28 Even if the standard of intent is somewhat different under the disparate treatment branch of Title VII (and it is not clear whether it is ${ }^{29}$ ), it is clear that no existing Title VII precedent has found disparate treatment liability for behavior that is the Title VII analogue of neglecting the distinctive building-access circumstances of individuals with disabilities.

Beyond the dimension of disparate treatment versus disparate impact liability, Title VII may also be broader - or narrower - than the Equal Protection Clause in certain other respects. For instance, with regard to the standard of liability for disparate treatment discrimination in the context of race, Title VII does not provide a "bona fide occupational qualification" defense (which it does provide for sex and national origin discrimination), ${ }^{30}$ yet Judge Richard Posner's opinion in Wittmer v. Peters ${ }^{31}$ found such a defense in a race case brought under the Equal Protection Clause. ${ }^{32}$ However, such differences in the standard of liability for disparate treatment discrimination are not material to my discussion here.

By an "accommodation" requirement for purposes of the analysis below, I mean a legal rule that requires employers to incur special costs in response to the distinctive needs (as measured against existing market structures) of particular, identifiable demographic groups of employees, such as individuals with (observable) disabilities, and imposes this requirement in circumstances in which the employer has no intention of treating the group in question differently on the basis of group membership (or "discriminating against" the group in the canonical sense). A concrete example will be helpful. Consider an employer who is required to provide a reader for a blind employee. Blind

27442 U.S. 256 (I 979 ).

28 Id. at 279 (citation omitted).

29 For a recent discussion of the Title VII intent standard, see Amy L. Wax, Discrimination As Accident, 74 IND. L.J. $1129,1146-52$ ( 1999 ).

3042 U.S.C. $\$ 2000 \mathrm{e}-2$ (e) (1994).

3187 F.3d 916 ( 7 th Cir. I 996$)$.

32 Id. at $918-21$. 
employees comprise a particular demographic group that is readily identifiable to outsiders. This employer is obviously required to incur special costs in connection with employing the blind employee. These obligations might well arise independently of any intention on the employer's part to treat blind employees differently from others on account of their blindness apart from the resulting need for readers; the employer's refusal to provide a reader without the legal mandate might well have stemmed purely from the cost of providing the reader. If in fact there was no intention to treat blind employees differently on account of their blindness apart from the resulting need for readers, then the requirement to provide a reader is an accommodation requirement within the definition used here. If, instead, the employer intentionally treated blind employees differently on account of their blindness apart from the resulting need for readers - even if its intentional differential treatment was simply a result of customers' or coworkers' attitudes toward blind individuals (for instance) rather than a result of its own views of such individuals - then the requirement is not an accommodation requirement within the definition used here.

This definition of an accommodation requirement captures the essence of the dichotomy noted in the Introduction between the canonical idea of "antidiscrimination" (intentional disfavoring of group members on account of their group membership, as in "we don't want any type X employees working here") and the concept of special or extra benefits for a particular group (apart from the requirement that group membership per se be ignored). I discuss the focus of the definition on the presence or absence of such intentional differential treatment by employers further at the beginning of Part III below. Intent in the definition here refers to the notion of intent reflected in existing disparate treatment doctrine, which was described just above.

The definition of an accommodation requirement offered here is largely a conceptual one, and in this respect it differs from the definition of antidiscrimination - based as it was on the Equal Protection Clause and Title VII - offered just above. But while the definition of an accommodation requirement is a conceptual one, it may usefully be illustrated by reference to specific employment law statutes.

The Family and Medical Leave Act provides a first illustration. The FMLA requires, among other things, that employers permit unpaid leave when an employee has a newborn child, ${ }^{33}$ and this requirement may well impose special costs on employers in connection with the employment of female employees of childbearing age, although it will also impose some costs in connection with the employment of prospective fathers. The FMLA also requires that employers permit un-

3329 U.S.C. \& $26 \mathrm{I} 2(\mathrm{a})(\mathrm{I})(\mathrm{A})(\mathrm{I} 994)$. 
paid leave for employees with medical conditions that make them unable to perform their job functions, ${ }^{34}$ and this requirement may well impose special costs on employers in connection with the employment of female employees of childbearing age (who, if they bear children, will be unable to work for at least a short period of time) and also individuals with disabilities, although again it will also impose some costs in connection with the employment of other individuals as well.

If an employer's failure to provide leave in the absence of the FMLA stemmed from an intent on its part to treat female or disabled employees differently on account of their sex or disability status rather than from a genuine concern with the business costs of providing the leave - then the FMLA provisions just described will not be accommodation requirements within the definition offered above. But in those cases in which the failure to provide leave was genuinely in response to the business costs (given existing market structures) of the leave, the requirement to provide leave is an accommodation requirement within the definition used here.

A second example of an accommodation requirement follows from the earlier illustration involving a blind employee. A requirement that employers take special steps in response to the distinctive needs (measured against existing market structures) of disabled employees may qualify as an accommodation requirement. The Americans with Disabilities Act requires employers to provide disabled employees, including those who are blind, with "reasonable accommodations" unless such accommodations would pose an "undue hardship" to the employer. ${ }^{35}$ This aspect of the ADA may require an employer to make physical modifications of a workplace or provide "assistive" technologies to aid in job performance. ${ }^{36}$ The ADA's "reasonable accommodations" provision requires employers to take special steps in response to the distinctive needs (measured against existing market structures) of disabled employees. Thus, the provision will be an accommodation requirement within the definition given here whenever the employer, prior to the legal mandate, refused to modify the workplace or provide helpful technology purely on grounds of the financial cost of doing so rather than based upon an intent to treat disabled employees differently on account of their group membership apart from any resulting need of theirs for "reasonable accommodations."

As the FMLA example illustrates, an accommodation requirement need not impose costs (relative to existing market structures) exclusively in connection with the employment of a single group to meet the

34 Id. \$ $26 \mathrm{I} 2(\mathrm{a})(\mathrm{I})(\mathrm{D})$.

3542 U.S.C. $\$ 12,112(a),(b)(5)(A)$.

36 Peter David Blanck, The Economics of the Employment Provisions of the Americans with Disabilities Act: Part I - Workplace Accommodations, 46 DEPAUL L. REV. 877, 892 (1997). 
definition used here; it is enough if the costs for a particular group are disproportionately large. Indeed, even the ADA's mandate of "reasonable accommodations," although nominally applicable only to individuals with disabilities (in contrast to the FMLA's more general, nonclass-specific provisions), may well create costs in connection with the employment of nondisabled employees to the extent that it establishes precedent for practices that ultimately benefit nondisabled employees as well as individuals with disabilities. ${ }^{37}$

\section{ANTIDISCRIMINATION AS ACCOMMODATION - CASES OF EQUIVALENCE}

Turning now to the substance of my argument, this first step examines aspects of antidiscrimination law - in particular its disparate impact branch - that are in fact accommodation requirements. This argument is not normative in any sense; it is simply that there is no way, as a factual matter, to distinguish the specified aspects of antidiscrimination law from requirements of accommodation.

The idea that certain aspects of disparate impact liability under antidiscrimination law are in fact accommodation requirements was appreciated by Reva Siegel and also (more briefly) by Linda Krieger and Patricia Cooney long ago in the specific context of pregnancy claims. $^{38}$ Krieger has also noted the idea in passing in recent work. ${ }^{39}$ But the point about the relationship between antidiscrimination and accommodation extends far more broadly than the pregnancy context, and it requires much greater elaboration and emphasis than it has received in other contexts. As explained below, important aspects of disparate impact liability under Title VII are in fact accommodation requirements.

These instances of equivalence between antidiscrimination and accommodation make it hard to argue that the two categories are fundamentally distinct rather than overlapping - yet many commentators have offered just such a view. ${ }^{40}$ Moreover, as described below, the overlap between the two categories has important implications for the

37 See, e.g., Lisa Bornstein, Inclusions and Exclusions in Work-Family Policy: The Public Values and Moral Code Embedded in the Family and Medical Leave Act, ro CoLUM. J. GENDER \& L. 77, $120(2000)$ (noting the value of employer rules allowing telecommuting to nondisabled employees with significant family obligations); Robert Ingle, Telecommuting: "Taking Your Work Home with You" Will Never Be the Same Again, 33 MD. B.J., Nov.-Dec. 2000, at 3, 6-7 (discussing whether telecommuting is required as a "reasonable accommodation" for individuals with disabilities under the ADA).

38 Siegel, supra note 15, at 940-46; Linda J. Krieger \& Patricia N. Cooney, The Miller-Wohl Controversy: Equal Treatment, Positive Action and the Meaning of Women's Equality, I3 GOLDEN GATE U. L. REV. 5 × 3, 559-6o (r983).

39 Krieger, supra note 16 , at $3-4$ \& n.14.

40 See sources cited supra note 16. 
hotly contested question of the scope of Congress's power under Section 5 of the Fourteenth Amendment to enact the FMLA and other federal employment laws.

\section{A. Disparate Impact Liability as Accommodation}

This section explains how certain important aspects of disparate impact liability are in fact accommodation requirements. Some background on disparate impact liability is important at the outset. The genesis of this form of liability is the Supreme Court's decision in Griggs v. Duke Power Co. ${ }^{41}$ in which the Court held that an employer could not use high school diplomas and general intelligence tests as conditions of employment because such conditions disproportionately harmed black candidates and were not sufficiently related to job performance. ${ }^{42}$ A leading gloss on the conception of disparate impact liability arising from this case is that disparate impact functions as a means of smoking out subtle or underlying forms of intentional discrimination on the basis of group membership. ${ }^{43}$

If disparate impact liability arose only in cases of underlying (though difficult-to-prove) intentional discrimination, then it would not require "preferential treatment" of any sort, as noted by Elizabeth Bartholet. ${ }^{44}$ Instead, it could easily be squared with the assumption that members of different groups "are inherently equal in ability and intelligence." 45 But disparate impact liability clearly sweeps more broadly, as the discussion to follow will make evident. Employers are often required by disparate impact law to incur special costs in response to the distinctive needs or circumstances (measured against existing market structures) of particular groups, and these requirements may arise in situations in which the employer had no intention of treating the group differently on the basis of group membership. Thus, important aspects of disparate impact law are in fact accommodation requirements.

As Siegel has perceptively noted, the gap between a robust conception (such as the one just described) of disparate impact liability and the narrower color (or sex) blindness rationale for the doctrine is reflected in the different accounts offered in Griggs itself. ${ }^{46}$ But while

4140 I U.S. 424 (197I).

42 Id. at $429-33$.

43 See, e.g., George Rutherglen, Disparate Impact Under Title VII: An Objective Theory of Discrimination, 73 VA. L. REV. 1297, I 309-I I (1987); David A. Strauss, Discriminatory Intent and the Taming of Brown, 56 U. CHI. L. REV. 935, 1010-II (I989).

44 Elizabeth Bartholet, Application of Title VII to Jobs in High Places, 95 HARV. L. REV. 945, $958-59$ ( 1982$)$.

45 Id. at 958 .

46 See Reva B. Siegel, Discrimination in the Eyes of the Law: How "Color Blindness" Discourse Disrupts and Rationalizes Social Stratification, 88 CAL. L. REV. 77, 95-96, 10I-02 (2000). 
Griggs may be ambivalent on the point, the post-Griggs case law and the Civil Rights Act of I99 I leave no doubt, I shall argue, about the existence and force of the broader conception. While some applications of disparate impact liability operate to smoke out underlying intentional discrimination, others impose requirements of accommodation.

A natural question to ask at this juncture, of course, concerns the rationale for the broader scope that the courts and Congress (in the Civil Rights Act of I $99 \mathrm{I}$ ) have given the disparate impact branch of Title VII. The natural answer to this question, of course, is that there is no easy, neat way of distinguishing those cases in which disparate impact in fact points to underlying intentional discrimination from those in which it does not. Some cases - such as many of the ones discussed below - may be more likely to fall on one side of the line than the other, but there is no good way to draw a clear line in advance between the two categories. For this reason the doctrine sweeps in both even as it asserts one as its target.

I. A First Example: Grooming Rules. - A first example of the way in which aspects of disparate impact liability are in fact accommodation requirements is that employers may be required by disparate impact law to excuse particular groups of workers (defined for instance by race) from facially neutral grooming rules that serve employers' business interests and were adopted solely for that reason. I begin with this example of facially neutral grooming requirements not because of its doctrinal or practical centrality (although it is far from unimportant from a practical perspective), but because the way in which disparate impact liability acts to require accommodation in this case is particularly clear. My discussion here does not address grooming rules that facially distinguish between groups, say by prohibiting long hair for male but not female employees.

The leading illustration of facially neutral grooming rules is the nobeard requirement imposed by many employers. Because the skin condition pseudofolliculitis barbae makes shaving impossible for a significant number of black men (and difficult for still more), but has no such effects on white males, some courts have found that a no-beard rule has an unlawful disparate impact on black men. ${ }^{47}$ For instance, in Bradley v: Pizzaco of Nebraska, Inc., ${ }^{48}$ the Eighth Circuit struck down a no-beard rule imposed by a Domino's pizza franchise on the ground that it had a disproportionately negative effect on black men

47 Bradley v. Pizzaco of Neb., Inc., 7 F.3d 795, 796-99 (8th Cir. I993); Richardson v. Quik Trip Corp., 591 F. Supp. I 5 I, I 153-56 (S.D. Iowa 1984); EEOC v. Trailways, Inc., 530 F. Supp. 54, 55-59 (D. Colo. 1981).

${ }^{48} 939$ F.2d 610 (8th Cir. I991) [hereinafter Bredley I]; 7 F.3d 795 (8th Cir. 1993) [hereinafter Bradley $I I]$. 
and was not justified by the business necessity requirement of disparate impact law. ${ }^{49}$ The court found that the Domino's franchise failed to show business necessity even though it had acted in response to perceived customer concerns about bearded employees. ${ }^{50}$

It is clear that a no-beard rule such as this could in some circumstances be used as a subtle means of effectuating underlying intentional discrimination against black employees, as it would screen them out disproportionately and yet is neutral on its face. (Catering to customers' preferences for clean-shaven employees is not a prohibited practice under Title VII, although catering to a preference for white employees obviously would be.) As described above, the way in which such a facially neutral rule could act as a cover for intentional discrimination on the basis of a protected characteristic such as race provides the central rationale for regulating such facially neutral practices under disparate impact liability.

But in many instances the application of disparate impact liability to facially neutral grooming rules is in fact an accommodation requirement, for two reasons. First, an employer such as the Domino's pizza franchise is required to incur special costs in response to the distinctive needs of a particular group of workers (black men in the nobeard example), as it must ignore its genuine business concern about customers' reaction to a particular aspect of its employees' appearance. In the Domino's case itself, although the court found that the employer had not demonstrated a business necessity for its no-beard rule, at trial the Domino's franchise had presented survey evidence that up to twenty percent of the public would "react negatively to a delivery man wearing a beard." 51 This evidence suggests that the no-beard rule had genuine support in valid business considerations, and that to abrogate it would impose real financial costs on the employer.

The second feature of an accommodation requirement is that the employer lacks any intention to treat a particular group of employees differently on the basis of group membership. The existence of genuine business grounds for a no-beard rule in a case such as Domino's suggests a genuine likelihood that the employer was acting in response to business concerns rather than based upon a subtle intention to exclude blacks from its workforce.

Of critical importance to the conclusion here that some cases of disparate impact liability for facially neutral grooming rules are in fact accommodation requirements is, of course, the scope of the business necessity criterion. This is so because if, contrary to the Domino's

\footnotetext{
49 Bradley $I, 939$ F.2d at 61 2-13; Bradley $I I, 7$ F.3d at 797-99.

50 Bradley $I I, 7$ F.3d at $798-99$.

51 Id. at 799.
} 
case, the existence of any sort of legitimate business ground were sufficient to satisfy the business necessity requirement, then disparate impact would rarely, if ever, extend beyond smoking out subtle forms of intentional discrimination (in circumstances in which no legitimate business ground of any sort could be advanced by the employer) and, thus, would rarely, if ever, require accommodation. Although a general definition of the business necessity criterion is elusive, the litigated cases in the grooming area, as well as those discussed in the sections to follow, make clear that this criterion requires something more than a legitimate business ground of some sort in support of the employer's challenged practice. Both the Domino's case and other cases involving no-beard policies have found disparate impact liability despite the existence of legitimate business grounds for the policies' adoption. ${ }^{52}$ These cases demonstrate the way in which the business necessity criterion "has teeth."

This is not to say, of course, that the business necessity criterion is never satisfied in grooming cases. In one case involving a no-beard rule, for instance, a court affirmed a grant of summary judgment for an employer on the ground that the need to ensure the fit of important safety equipment on the face qualified as a business necessity. ${ }^{53}$ But the Domino's example and other similar cases make clear that not all genuine business considerations (such as twenty percent of the public "react[ing] negatively" to bearded delivery personnel ${ }^{54}$ ) are enough to support a showing of business necessity.

Remedies in the no-beard cases discussed above that have been decided in favor of employees nicely highlight the fundamental equivalence between disparate impact liability and requirements of accommodation. Courts typically have required employers to exempt black men who are unable to shave from rules prohibiting beards. ${ }^{55}$ Thus, quite directly in these cases, disparate impact liability requires employers to incur special costs in response to the distinctive needs (measured against existing market structures) of a particular group of employees.

But even if a court were to strike down a no-beard policy in general (the more usual approach in the disparate impact arena outside of the no-beard cases ${ }^{56}$ ), the end result would still be that employers would be required, in practical effect, to incur special costs in response

52 E.g., id. at 798-99; Richardson, 59 I F. Supp. at I 155 .

53 Fitzpatrick v. City of Atlanta, 2 F.3d I I I2, I I I8-2 I (I Ith Cir. 1993).

54 Bradley $I I, 7$ F.3d at 799.

55 See id.; EEOC v. Trailways, 530 F. Supp. 54, 59 (D. Colo. 198I). In Richardson, the plaintiff sought only monetary relief, 591 F. Supp. at 1156 , but the court nonetheless chose to state that the employer could enforce the "no-beard policy against all employees except those who provide a medical certificate" showing they could not shave, $i d$. at I 55 .

56 See, e.g., Wendy W. Williams, Equality's Riddle: Pregnancy and the Equal Treatment/ Special Treatment Debate, 13 N.Y.U. REV. L. \& SoC. CHANGE 325, 368 (1984-85). 
to the distinctive needs (measured against existing market structures) of a particular group. This is so because black men would be disproportionately, though not exclusively, benefited by the legal intervention, akin to the situation in the previously discussed case of the FMLA. As Owen Fiss has noted in discussing disparate impact claims, "a flat ban on use of the criterion will have a differential impact on the two classes." 57

Thus, requirements that employees be exempted from no-beard rules, or even that such rules be abrogated across the board, provide a first example of the way in which certain applications of disparate impact liability are in fact accommodation requirements.

2. A Second Example: Job Selection Criteria. - Disparate impact liability may also impose requirements of accommodation in the most familiar context in which this form of liability operates - that of facially neutral hiring screens or tests that disproportionately disadvantage a particular group. Examples here include height and weight requirements, which tend to exclude women at a higher rate than men, ${ }^{58}$ and general ability testing, which typically excludes certain racial groups at higher rates than others. ${ }^{59}$ Sometimes (perhaps often) these requirements may be used as a means to effectuate intentional differential treatment of a particular group on the basis of group membership. For instance, height and weight requirements may often have been used in the past (or even now) as a cover for intentionally excluding women from certain positions. But even when a hiring criterion was not imposed in an effort to exclude a particular group, and even when the criterion does bear a reasonable relation to job performance, the criterion may nonetheless be unlawful as a matter of disparate impact law. In such circumstances disparate impact liability acts as an accommodation requirement.

A prominent recent example of a case involving job selection criteria is Lanning $v$. Southeastern Pennsylvania Transportation Authority. ${ }^{60}$ The court there reversed a judgment in favor of an employer and held that an employment screen requiring transit police officers who might have to apprehend suspects on foot to run 1.5 miles in twelve minutes - a screen that disproportionately disqualified women - might not be justified by business necessity. ${ }^{61}$ This was so, the court held, even though the employer had adopted the screen "in response to a perceived need to upgrade the quality of its transit police

\footnotetext{
57 Owen M. Fiss, A Theory of Fair Employment Laws, 38 U. CHI. L. REV. 235, 304 (197 1).

58 See, e.g., Dothard v. Rawlinson, 433 U.S. 32 I, 329-30 (1977).

59 See, e.g., Mark Kelman, Concepts of Discrimination in "General Ability" Job Testing, 104 HARV. L. REV. I157, II58 (I991).

60 I8I F.3d 478 (3d Cir. 1999), cert. denied, 528 U.S. I I 31 (2000).

61 Id. at $485,49 \mathrm{I}-94$.
} 
force,"62 and even though studies revealed "a statistically significant correlation between" aerobic capacity (measured by the screen) and "arrests, arrest rates and commendations."63

Invalidating the employer's selection rule in the Lanning case would require the employer to incur special costs in connection with the employment of female officers, as women would be disproportionately likely to fail the twelve-minute test, a test that obviously bore at least some relation to success in apprehending offenders. Indeed, because of the relevance of the test, the Bush administration recently withdrew from participation on the employees' side of the case. ${ }^{64}$ If, as certainly is possible, the employer had adopted the twelve-minute test without any intention of excluding women from the transit police force, then - in light of the costs of abandoning the screen - its invalidation under disparate impact law would impose an accommodation requirement on the employer.

A second recent example of the way in which disparate impact liability for job selection criteria may operate to require accommodation is provided by Banks $v$. City of Albany. ${ }^{65}$ There the court refused to grant summary judgment to a fire department whose policy of subjective hiring based on personal contacts and familial relationships was challenged because of the policy's negative effect on black candidates. ${ }^{66}$ "Although it may be inferred that familial ties to the Albany Fire Department and a close personal relationship with Chief Larson are an indication of future excellence as a firefighter, Defendants offer no support for the proposition that the Chief's subjective criterion is a business necessity ...." 67 Although the case involved a decision that the employer was not entitled to summary judgment rather than a final resolution of the case after a full trial, the foregoing quotation makes clear that the Banks court rejected the employer's business necessity claim not on the ground that it rested on disputed material facts that prevented summary judgment, but instead on the ground that the justification offered by the employer was simply inadequate to establish business necessity.

In Banks, it is possible that the department's hiring practices were adopted for other than purely business-related reasons - for instance, to preserve the racial composition of the existing force. But it is also

62 Id. at $48 \mathrm{I}$.

63 Id. at 484 . On remand, the district court found for the employer, as it had the first time around. Lanning v. Southeastern Pa. Transp. Auth., 84 Fair Empl. Prac. Cas. IOI2, roz8-32 (2000).

64 Ellen Nakashima, Justice Dept. Bows Out of a Civil Rights Case, WASH. Post, Oct. 2, 200r, at A23.

65953 F. Supp. 28 (N.D.N.Y. 1997).

66 Id. at $33-36$.

67 Id. at 36 . 
quite possible that the department was genuinely - and correctly acting to maximize the effectiveness and long-term commitment of its workforce. The Banks court notes that a candidate lacking the personal or familial connections sought by the department might nonetheless have "years of experience as a firefighter, perhaps even experience as a fire chief," 68 but still it seems distinctly possible that someone with a personal connection would be preferable from the departmental perspective of maximizing commitment, trust, and stability of the force. And if in fact the department was (correctly) acting on this ground rather than based upon an intent to keep black candidates out, then the effect of a finding of disparate impact liability, and the concomitant invalidation of the department's job selection criteria, would be to impose an accommodation requirement on the employer, much as in the Lanning case.

3. A Third Example: English-Only Requirements. - A third case in which aspects of disparate impact liability are in fact accommodation requirements involves the application of disparate impact liability to employers' English-only rules. Some employers forbid their employees to speak languages other than English at the workplace, and these facially neutral rules may create an unlawful disparate impact on the basis of national origin. Last year alone the Equal Employment Opportunity Commission (EEOC) received 443 complaints challenging English-only policies in the workplace. ${ }^{69}$

A recent example of a case involving an English-only rule is $E E O C$ v. Synchro-Start Products, Inc. ${ }^{70}$ In that case an employer forbade all employees, including those who spoke little or no English, to speak any foreign language at the workplace. ${ }^{71}$ The court held that the employer's English-only rule "unarguably impacts people of some national origins (those from non-English speaking countries) much more heavily than others" and that further proceedings were needed to determine whether the employer's policy met the business necessity requirement of disparate impact law. ${ }^{72}$ Synchro-Start subsequently chose to settle the case. ${ }^{73}$

A recent challenge to an English-only policy in Texas likewise produced a favorable settlement for employees. There the EEOC claim netted a startling $\$ 2.44$ million for a group of eighteen Hispanic em-

$68 I d$.

69 T. Shawn Taylor, A New Language Barrier: More Businesses Are Requiring English To Be Spoken on the Job, CHI. TRIB., June ro, 2001 , $\$ 6$ (Working), at I.

7029 F. Supp. 2 d 911 (N.D. Ill. 1999).

71 Id. at 912 .

72 Id. at 91 2-I4 \& n.7 (applying 29 C.F.R. \$ I606.7 (2000) (EEOC English-only rule)).

73 Taylor, supra note 69 , at 7 . 
ployees who were required to speak exclusively English on the job and who were verbally and physically harassed for violations of this rule. ${ }^{74}$

It is clear how an English-only policy - particularly one that, like in the Texas case, applies during break periods as well as while working ${ }^{75}$ - may be a covert means of effectuating intentional discrimination on the basis of national origin. However, in the case of the Synchro-Start policy noted above, the reason for adopting the rule was apparently a complaint by an employee who believed that her coworkers were using their Spanish language ability to speak ill of her without her being able to understand their comments. ${ }^{76}$ As numerous courts and commentators have emphasized, the negative effects on employee morale that such coworker behavior causes may certainly provide a genuine business ground for the adoption of an English-only rule. ${ }^{77}$ Nonetheless, this ground may not rise to the level of business necessity because, as described in preceding sections, business necessity requires more than merely a plausible business reason for the challenged practice. If, in a given case, an English-only policy was adopted without any intent to treat an employee group differently on the basis of group membership, and if eliminating the policy would impose costs on the employer in the form of poor coworker morale or other difficulties, then disparate impact liability for an English-only policy is an accommodation requirement.

Of course, in some circumstances English-only rules are permissible under disparate impact law, including in cases in which employees have proficiency in English and therefore, according to many (though not all) courts, are not significantly burdened by a requirement that English be the sole language spoken in the workplace. ${ }^{78}$ There appear to be no reported cases, however, in which an English-only policy that burdens employees with limited or no English proficiency has been

74 Id.

75 Id.

76 Id.

77 E.g., Kania v. Archdiocese of Philadelphia, 14 F. Supp. 2d 730, 736 (E.D. Pa. 1998); Prado v. L. Luria \& Son, Inc., 975 F. Supp. 1349,1357 (S.D. Fla. 1997); S. Craig Moore, English-Only Rules in the Workplace, I5 LAB. LAW. 295, 296-98 (1999).

78 See Garcia v. Spun Steak Co., 998 F.2d I480, 1487-88 (gth Cir. 1993); Garcia v. Gloor, 618 F.2d 264, 270-7I (5th Cir. 1980); Roman v. Cornell Univ., 53 F. Supp. 2d 223, 237 (N.D.N.Y. 1999); Kania, 14 F. Supp. 2d at 736; Tran v. Standard Motor Prods., Inc., ro F. Supp. 2d Irg9, 12 I (D. Kan. 1998); Prado, 975 F. Supp. at 1354; Long v. First Union Corp., 894 F. Supp. 933, 94I (E.D. Va. 1995), affd, 86 F.3d 115 I (4th Cir. 1996); Gonzalez v. Salvation Army, No. 89-1679CIV-T-I 7, I 99 I U.S. Dist. LEXIS 21692 , at *4 (M.D. Fla. June 3, I991). But see EEOC v. Premier Operator Servs., Inc., I 3 F. Supp. 2d 1066, 1075-76 (N.D. Tex. 2000) (reaching the opposite conclusion about the effect of English-speaking ability on the viability of a disparate impact claim). 
upheld on grounds of the employer's business necessity. ${ }^{79}$ Again, this suggests the reach and the scope of the business necessity requirement of disparate impact law and, accordingly, the way in which some aspects of disparate impact liability are in fact accommodation requirements.

4. A Fourth Example: Pregnancy. - As Siegel and others have explained, the logic of disparate impact liability requires employers to provide certain benefits, such as leave from work, to pregnant employees. ${ }^{80}$ As this conclusion suggests, and as elaborated further below, the pregnancy setting thus provides yet another example of the way in which some applications of disparate impact liability are in fact accommodation requirements.

79 As just noted, many of the reported cases involve situations in which employees have some English proficiency, and in these cases employers often win on the ground that their English-only rules do not significantly burden employees. See Spun Steak Co., 998 F.2d at 1487-88; Gloor, 618 F.2d at 270-71; Roman, 53 F. Supp. 2d at 237 ; Kania, 14 F. Supp. 2d at 736 ; Tran, ro F. Supp. 2 d at 12 I I; Prado, 975 F. Supp. at 1354 ; Long, 894 F. Supp. at 941 ; Gonzalez, I 99 I U.S. Dist. LEXIS 21692 , at $* 4$. In many of these cases, the court also noted the business grounds supporting the imposition of an English-only rule. Roman, 53 F. Supp. 2d at 237 ; Kania, 14 F. Supp. 2d at 736 ; Tran, 10 F. Supp. 2d at I 2 IO-1 I; Prado, 975 F. Supp. at 1357; Long, 894 F. Supp. at 94 I-42; Gonzalez, 1991 U.S. Dist. LEXIS 21692 , at *7. But in none of these instances did the court reach any conclusion as to the business necessity of the rule. (The Kania court is thus incorrect when it states that in Prado the court found the English-only rule at issue to be supported by business necessity. See Kania, I4 F. Supp. 2d at 735. Prado simply found that the rule "further[ed] a legitimate business interest." Prado, 975 F. Supp. at 1357.) The Kania court concluded (in dicta, as it had already ruled against the employees on the ground that their English proficiency refuted any real burden of an English-only rule) that the rule in question had a "valid business justification," Kania, I4 F. Supp. 2d at 736, but the court made no finding of business necessity in support of the rule. Tran is similar to Kania. See Tran, 10 F. Supp. $2 \mathrm{~d}$ at 12 10-11. Meanwhile, in Long v. First Union Corp., No. 95-I 986, I996 WL 281954 (4th Cir. May 29, 1996), the Fourth Circuit ruled in favor of the employer on a claim of discriminatory application of an English-only rule, but the appeal did not raise any issue about the general permissibility of the rule itself, see id. at $*_{1} \&$ n.2. The employer in Velasquez v. Goldwater Memorial Hospital, 88 F. Supp. 2d 257 (S.D.N.Y. 2000), likewise prevailed, but the case was argued purely on a disparate treatment theory, id. at $26 \mathrm{I}-62$, and thus there was no issue of business necessity under disparate impact law. Similarly, no issue of business necessity was raised in Gotfryd v. Book Covers, Inc., No. 97-C7949, 1999 U.S. Dist. LEXIS 235 (E.D. Ill. Jan. 6, 1999); the employer prevailed there because of the small number of incidents involving use of a foreign language that had occurred and the absence of an explicit policy requiring the use of English, id. at *8-24. Finally, as already noted, some courts rule in favor of employees on challenges to English-only rules. See Premier Operator Services, I I3 F. Supp. 2d at 1073-76; EEOC v. Synchro-Start Prods., Inc., 29 F. Supp. 2d 9I I, 91 2-I4 (N.D. Ill. 1999); Saucedo v. Bros. Well Serv., Inc., 464 F. Supp. 919, 922-23 (S.D. Tex. 1979). In two of these three cases (Premier Operator Services and Saucedo), the court explicitly found that the employer's English-only policy was not justified by business necessity. Premier Operator Services, I 3 F. Supp. 2d at 1070-71, 1073; Saucedo, 464 F. Supp. at 922.

80 Deborah A. Calloway, Accommodating Pregnancy in the Workplace, 25 STETSON L. REv. I, 39-40, 42-43 (I 995); Krieger \& Cooney, supra note 38, at 525 \& n.40, 559-60; Laura Schlichtmann, Comment, Accommodation of Pregnancy-Related Disabilities on the Job, 15 BERKELEY J. EMP. \& LAB. L. 335, 370-88, 403-04 (I 994); Siegel, supra note 15, at 940-46. 
As just suggested, a central application of disparate impact liability in the pregnancy context involves the provision of leave time from work. Some courts hold that facially neutral employer policies permitting no or limited time off for illness or disability (including pregnancy) create an unlawful disparate impact on female employees. Thus, for example, in EEOC $v$. Warshawsky \& Co., ${ }^{81}$ the court granted summary judgment against an employer on the ground that its policy of discharging all first-year employees who requested long-term sick leave had a disproportionately negative effect on women (because of their ability to become pregnant) and was not justified by business necessity. ${ }^{82}$ Other courts have similarly ruled in favor of employees on disparate impact claims challenging the absence of leave time. ${ }^{83}$ The EEOC guidelines likewise provide that the absence or inadequacy of a leave policy may create an unlawful disparate impact on female employees. ${ }^{84}$

Since the enactment of the Family and Medical Leave Act, the failure to provide an appropriate leave period is independently unlawful; the FMLA requires medical leave for employees with conditions (including pregnancy-related conditions) that prevent them from performing their job functions. ${ }^{85}$ Section II.C below discusses the implications of this parallel between the FMLA and disparate impact liability for the current controversy over Congress's power under Section 5 of the Fourteenth Amendment to enact the FMLA's medical leave provision.

As suggested by the parallel between disparate impact law and the FMLA - which was one of the laws used in Part I above to illustrate the concept of an accommodation requirement - some aspects of disparate impact liability in the pregnancy context are in fact accommodation requirements. This is so because the provision of medical leave, even unpaid medical leave, entails real financial costs for employers in connection with the employment of women of childbearing age (as well

81768 F. Supp. 647 (N.D. Ill. I991).

82 Id. at $65 \mathrm{I}-55$. As noted below, the Warshawsky court found the absence of a business necessity despite the fact that it was applying a more employer-friendly framework for business necessity than the one that exists today. See infra note 1 I 3 .

83 E.g., Abraham v. Graphic Arts Int'l Union, 660 F.2d 81 1, 81 8-20 (D.C. Cir. 1981) (reversing a grant of summary judgment for an employer because a pregnant employee had shown that the employer's ten-day leave limitation had a disparate impact on women and the employer had not adequately defended its approach); Miller-Wohl Co. v. Comm'r of Labor \& Indus., 692 P.2d r 243, I 25 I-52 (Mont. I984) (concluding, in the course of upholding a state law requiring leave for pregnancy, that an employer's no-leave policy for first-year employees had a disparate impact on women), vacated and remanded, 479 U.S. 1050 (1987), judgment and opinion reinstated, 744 P.2d 871 (Mont. 1987).

8429 C.F.R. § I604.IO(c) (2000).

8529 U.S.C. $\$ 2612$ (a)(I)(D) (1994). 
as other employees who use such leave), ${ }^{86}$ and thus a legal rule requiring such leave is an accommodation requirement whenever an employer's prior failure to provide the leave reflected these business costs rather than an intent to exclude female employees on account of their sex. Of course, the failure to provide any sort of medical or sick leave might in some cases reflect underlying intentional discrimination against women, who are more likely to need such leave because of their ability to become pregnant. But it is equally clear that this failure could reflect purely the business costs of offering such leave.

As noted above, several commentators pointed out the relationship between disparate impact liability and accommodation of pregnancy almost two decades ago. ${ }^{87}$ Nonetheless, other commentators have often overlooked the point. These commentators have asserted, without explaining why Title VII's disparate impact branch is not to the contrary, that employers are under no obligation to avoid facially neutral practices that disproportionately harm female employees; instead, according to these commentators, employers must simply avoid singling out pregnancy for worse treatment than other conditions. For instance, it is sometimes contended that (apart from the FMLA) firms need not offer leave for childbirth unless such leave is offered for other health conditions. ${ }^{88}$ One author writes, "[A]n employer who promptly discharges an employee who becomes disabled may also fire the disabled pregnant employee." 89 Another states that "employers [must] make available to pregnant women only what they make available to men for other conditions." 90

These commentators' views are quite puzzling. It is almost as if the very existence of the disparate impact branch of liability under Title VII is being ignored, often based on a reading of the second clause

${ }^{86}$ See, e.g., Samuel Issacharoff \& Elyse Rosenblum, Women and the Workplace: Accommodating the Demands of Pregnancy, 94 COLUM. L. REv. 2 I54, 2 I91-92 (1994).

${ }_{87}$ See Krieger \& Cooney, supra note 38, at 559-60; Siegel, supra note 15, at 940-46.

88 E.g., ROBERTA M. SPALTER-ROTH \& HEIDI I. HARTMANN, UNNECESSARY LosSes: COSTS TO AMERICANS OF THE LACK OF FAMILY AND MEDICAL LEAVE 3, 4I (I990).

89 Maria O'Brien Hylton, "Parental" Leaves and Poor Women: Paying the Price for Time Off, 52 U. PITT. L. REV. 475, 506 n.I 38, 512 (I991).

90 Lucinda M. Finley, Transcending Equality Theory: $A$ Way Out of the Maternity and the Workplace Debate, 86 COLUM. L. REV. I118, 1125 (I986). At various points, Wendy Williams offers similar-sounding statements about the permissibility of facially neutral rules that may disproportionately burden female employees. Williams, supra note 56 , at 348,350 n.ro2, 351 . However, her detailed discussion of disparate impact liability in the pregnancy context, see id. at $364-$ $65,372-73$, suggests that what she may actually mean by the earlier statements is that, while disparate impact liability may indeed invalidate facially neutral rules, women in such cases are not entitled to any special exemption from such rules; instead these rules must be invalidated across the board. See id. at 368-69. But the idea that across-the-board invalidation means the absence of any special benefit for women overlooks Fiss's correct observation that even a "flat ban" on a practice that has a disparate impact will produce differential benefits for various groups. Fiss, supra note 57 , at 304 . 
of the Pregnancy Discrimination Act of 1978 (PDA) ${ }^{91}$ that the Supreme Court appears, in California Federal Savings $\mathcal{E}$ Loan Ass'n v. Guerra, ${ }^{92}$ to have rejected. ${ }^{93}$ Indeed, the Reagan Justice Department tried unsuccessfully to argue precisely the claim that disparate impact liability was not available in the pregnancy context, but the Seventh Circuit, in an important decision, Scherr v. Woodland School Community Consolidated District No. 50,94 promptly rejected this contention. The Scherr court relied heavily on the Supreme Court's decision in Guerra and held that summary judgment had been improperly granted for an employer on a disparate impact claim brought by a pregnant employee. ${ }^{95}$ Indeed, even a Title VII minimalist such as Richard Epstein concludes that "it appears that the full apparatus of disparate impact would apply to pregnancy cases under the statute, as it does to ordinary cases of sex discrimination." 96

To be sure, the pregnancy context differs from the examples discussed in the prior sections in the sense that there is some unrest, and even some outright conflict, in the case law. While the pregnancy cases discussed above point to the way in which aspects of disparate impact liability are in fact accommodation requirements, other decisions in the pregnancy context (not, however, cited by the commentators who deny any legal obligation to take special steps in response to the circumstances of pregnant employees) offer narrower conceptions of disparate impact liability.

The leading example here is Judge Richard Posner's opinion in Troupe v. May Department Stores $C_{0 .}{ }^{97}$ The employee there had been fired after repeatedly arriving late to work because of morning sick-

9142 U.S.C. \& $2000 \mathrm{e}(\mathrm{k})$ (1994).

92479 U.S. $272(1987)$.

93 See id. at 284-86. Spalter-Roth and Hartmann, Hylton, and Williams all invoke the second clause of the PDA. SPALTER-ROTH \& HARTMANN, supra note 88, at 3; Hylton, supra note 89, at 506 n.138; Williams, supra note 56 , at 348 . But the Guerra Court, after giving its (seemingly different) interpretation of this clause, cemented the contrast with the view of these authors by stating that "[s]everal commentators have construed the second clause of the PDA in [the way it was describing]." Guerra, 479 U.S. at $285 \&$ n.16. The sources cited by the Court are Siegel, supra note 15, at 937, and Andrew Weissman, Note, Sexual Equality Under the Pregnancy Discrimination Act, 83 COLUM. L. REV. 690,693 \& $\mathrm{n.26}$ (1983). As described above, Siegel's central thesis is that disparate impact liability requires special steps in response to the needs of pregnant employees. Likewise, Weissman's essential argument, although not phrased in terms of disparate impact, is that the law requires various forms of special treatment for pregnant employees. See Weissman, supra, at 693-97, 709-21. The reference to Siegel's and Weissman's articles is thus inconsistent with the idea that employers' sole legal obligation is to avoid singling out pregnancy for worse treatment than other conditions.

94867 F.2d 974 (7th Cir. 1988).

95 Id. at $977-8 \mathrm{I}, 983-84$.

96 Richard A. EPSTEIN, Forbidden Grounds: The CASE AgaInst EMPloyment DISCRIMINATION LAWS 349 (1992).

9720 F.3d 734 (7th Cir. 1994). 
ness and just before beginning a scheduled medical leave of absence from which the employer apparently feared she would not return. ${ }^{98}$ Judge Posner acknowledged the general availability of disparate impact liability in the pregnancy context but then rejected its applicability to the case at hand on the ground that disparate impact liability cannot serve, he wrote, as "a warrant for favoritism." according to Judge Posner, "can treat pregnant women as badly as they treat similarly affected but nonpregnant employees."100 The treatment of disparate impact liability in Troupe is arguably dicta because "the only kind of discrimination alleged" in the case was disparate treatment, ${ }^{101}$ but subsequent courts have relied on Troupe as the basis for their disparate impact holdings. ${ }^{102}$

Dormeyer v. Comerica Bank-Illinois, ${ }^{103}$ another Posner opinion, is similar to Troupe. Dormeyer offered a narrow vision of disparate impact liability, a form of liability that, Judge Posner wrote, exists to identify situations in which, "through inertia or insensitivity, companies [are] following policies that gratuitously - needlessly — although not necessarily deliberately, exclude[] black or female workers from equal employment opportunities." 104 Dormeyer, like Troupe and other opinions relying on Troupe, did not offer a response to any of the contrary judicial authority, from either pregnancy or non-pregnancy cases, discussed above. ${ }^{105}$

The version of disparate impact liability reflected in Troupe and Dormeyer - and also in some non-pregnancy cases, such as the Finnegan decision (also authored by Judge Posner) quoted in Dormeyer ${ }^{106}$ - cannot be squared with the body of case law discussed up to now. Starting with the Domino's case discussed in section II.A.I above, this case law shows that business necessity requires something more than a minimal business justification or a showing that the policy in question

\footnotetext{
98 Id. at $735-36$.

99 Id. at 738 .

100 Id.

101 Id. at 736.
}

102 Dormeyer v. Comerica Bank-Ill., 223 F.3d 579, 583 (7th Cir. 2000); Kennedy v. Schoenberg, Fisher \& Newman, Ltd., No. 93-C-4518, r 997 WL 285488 , at ${ }^{*}{ }_{13}$ (N.D. Ill. May 19, 1997), aff'd, 1 40 F.3d 716 (7th Cir. 1998). Armstrong v. Flowers Hospital, Inc., 33 F.3d 1308, 1316-1 7 (1 1 th Cir. I994), also relied on Troupe in discussing a pregnant employee's disparate impact claim, but it had already ruled against the employee on that claim because of an evidentiary failure to establish the adverse effect of the challenged policy on pregnant employees. Id. at $1315-16$.

103223 F.3d 579 (7th Cir. 2000).

104 Id. at 583 (quoting Finnegan v. Trans World Airlines, Inc., 967 F.2d I16I, II64 (7th Cir. I 992)) (emphasis added).

105 For a criticism of Troupe on this ground, see Schlichtmann, supra note 80 , at $408 \mathrm{nn} .492$, 495.

106 See Dormeyer, 223 F.3d at 583 (quoting Finnegan, 967 F.2d at 1164 ). 
is not, to use the terminology of Finnegan, "gratuitous[]."107 The Finnegan conception, also reflected in Troupe and Dormeyer, is a significant departure from the case law discussed previously. And, as described just below, this conception seems especially hard to justify after the passage of the Civil Rights Act of I99I.

5. The Concept of "Business Necessity" in the Supreme Court and in Congress. - As just described, disparate impact liability may impose requirements of accommodation through its invalidation of facially neutral rules that disproportionately burden particular groups of employees. Also as discussed above, critical to the overlap between disparate impact liability and requirements of accommodation is the scope of the business necessity criterion. This is so because if, contrary to most of the cases discussed above, the business necessity criterion required merely some legitimate business ground for the employer's decision, then disparate impact liability would rarely, if ever, operate to require accommodation; instead, it would function largely or exclusively as a way to smoke out subtle forms of intentional discrimination (in circumstances in which no legitimate business ground could be advanced by the employer).

The scope of the business necessity criterion was the subject of an important controversy in the Supreme Court in the late I980s. Justice O'Connor's plurality opinion in Watson v. Fort Worth Bank E Trust ${ }^{108}$ offered a deferential formulation of business necessity; employers were merely required to have a "legitimate business purpose[]" for the practice challenged under disparate impact law. ${ }^{109}$ The following year, the recently appointed Justice Kennedy joined the four members of the Watson plurality to form a majority in Wards Cove Packing Co. v. Atonio,"10 which held that "the dispositive issue" for purposes of the business necessity criterion was "whether a challenged practice serves, in a significant way, the legitimate employment goals of the employer."11 "A mere insubstantial justification," according to the Court, "will not suffice, because such a low standard of review would permit discrimination to be practiced through the use of spurious, seemingly neutral employment practices."112 But, the Court concluded, the challenged practice need not be "essential' or 'indispensable' to the employer's business for it to pass muster." 113

\footnotetext{
107 Finnegan, 967 F.2d at $1 \times 64$.

108487 U.S. 977 (1988).

109 Id. at 999 .

110490 U.S. 642 (1989).

111 Id. at 659.

112 Id.

113 Id. The Wards Cove standard was the one applied by the court in EEOC v. Warshawsky, 768 F. Supp. 647 (N.D. Ill. I99I), discussed in the preceding section. See id. at 655; supra note 82.
} 
Whether the opinions in Watson and Wards Cove reflected a retreat from earlier Supreme Court formulations of the business necessity criterion is the subject of some dispute. ${ }^{114}$ But what is clear is that to the extent Wards Cove (the only opinion that was binding precedent, as Watson was only a plurality opinion) did mark such a retreat, it is no longer good law. In the Civil Rights Act of I99I, Congress specifically employed the phrase "business necessity" to describe what was required for an employer to prevail in a disparate impact case. ${ }^{115}$ The interpretive memorandum accompanying the relevant portion of the Act states that "business necessity" is "intended to reflect the concepts enunciated by the Supreme Court in Griggs v. Duke Power Co., and in the other Supreme Court decisions prior to Wards Cove Packing Co. $v$. Atonio."16 Furthermore, the Act provides that this interpretative memorandum is the only source of legislative history that may be "relied upon in any way" in interpreting the business necessity requirement imposed by the Act. ${ }^{117}$ Thus, whether or not the majority opinion in Wards Cove altered the business necessity standard (and certainly the interpretive memorandum quoted above suggests Congress's own view of the matter), the rule after I99I is that the business necessity criterion must be met free of any dilution by Wards Cove. The Lanning and Bradley v. Pizzaco of Nebraska opinions discussed above take the same view. ${ }^{118}$ While a majority of the Supreme Court is perhaps inclined toward a somewhat narrower conception of disparate impact liability, Congress has made clear its preference, which, in this area of statutory law, is of course controlling.

\section{B. Implications for the Relationship Between Antidiscrimination and Accommodation}

Many commentators have suggested that antidiscrimination (defined in terms of existing constitutional and Title VII law, as stated above) and accommodation are fundamentally distinct rather than overlapping notions. ${ }^{119}$ But the insights offered here into aspects of disparate impact liability that are in fact accommodation requirements suggest some obvious difficulties with this common view. The present

114 Compare Note, The Civil Rights Act of rggr: The Business Necessity Standard, yo6 HARV. L. REV. 896, 899 (r993) (suggesting retreat), with Michael Carvin, Disparate Impact Claims Under the New Title VII, 68 NOTRE DAME L. REV. I I53, I I6I-62 (1993) (suggesting no retreat).

11542 U.S.C. \& $2000 \mathrm{e}-2(\mathrm{k})(\mathrm{I})(\mathrm{A})(\mathrm{i})$ (1994).

116137 CONG. REC. 28,680 (199I) (internal citations omitted).

117 Civil Rights Act of r99 I, Pub. L. No. 102-I66, § 105(b), 105 Stat. 1071, 1075 (1991).

118 Lanning v. Southeastern Pa. Transp. Auth., 18I F.3d 478, 488 \& n.I3 (3d Cir. 1999); Bradley $I I, 7$ F.3d 795, 797 (8th Cir. 1993).

119 See sources cited supra note 16. 
section describes and responds to claims that antidiscrimination and accommodation are sharply different categories.

I. Distinguishing Antidiscrimination from Accommodation. - As a first example of the idea that antidiscrimination (as defined under existing constitutional and Title VII law) and accommodation are fundamentally distinct rather than overlapping categories, Pamela Karlan and George Rutherglen argue, in a prominent article on the Americans with Disabilities Act, that this Act's express requirement that employers "mak[e] reasonable accommodations" to the needs of individuals with disabilities sets the ADA "profound[ly]" apart from Title VII. ${ }^{120}$ Citing Title VII, Karlan and Rutherglen contend that "under the civil rights statutes that protect women [and] blacks ... plaintiffs can complain of discrimination against them, but they cannot insist upon discrimination in their favor." 121 The authors explicitly contrast this approach with the ADA's express mandate of "reasonable accommodations." 122 But the difficulty with this view is that it fails to recognize the case law, discussed above, imposing accommodation requirements as a matter of Title VII disparate impact law. As described in section II.A above, important aspects of disparate impact liability under Title VII require employers to incur special costs in response to the distinctive needs and circumstances (measured against existing market structures) of particular groups and impose such requirements even in the absence of any intentional differential treatment of such groups by the employer - just as various applications of the ADA's express mandate of "reasonable accommodations" have this pair of features, as noted in Part I above. Even when the remedy for a finding of disparate impact under Title VII is an across-the-board abrogation of the challenged practice instead of merely an exemption for a particular group, the application of disparate impact liability is an accommodation requirement because, as noted above, even "a flat ban on use of the criterion will have a differential impact on the two classes." 123

The notion that antidiscrimination and accommodation are fundamentally distinct rather than overlapping categories is also a theme voiced by Samuel Issacharoff and Justin Nelson. These authors contend that "the ADA marks a ... departure" from Title VII, even from Title VII's regulation of "facially-neutral criteria" under the disparate impact branch of the law. ${ }^{124}$ "[U]nder the ADA," they write, "there is

\footnotetext{
120 Karlan \& Rutherglen, supra note I6, at $4 \mathrm{I}$.

121 Id. at 3 (emphasis added).

122 Id. at $2-4$.

123 Fiss, supra note 57 , at 304

124 Issacharoff \& Nelson, supra note 16 , at 315. To be precise, Issacharoff and Nelson refer to the use of facially neutral criteria in education rather than in the employment setting regulated by
} 
an intervening duty to alter the work environment, even if a disabled employee may never be as productive as a non-disabled potential employee."125 But their claimed contrast between Title VII and the ADA's "reasonable accommodations" mandate overlooks the way in which, as described above, Title VII likewise requires employers to "alter the work environment, even if [the] employee may never be as productive as [other] potential employee[s]." When, for instance, disparate impact law prohibits facially neutral grooming rules that maximize an employer's profits, this law is requiring an employer to "alter the work environment" in response to the circumstances of individuals who are less effective employees from the employer's profit-maximizing business perspective.

Like Issacharoff and Nelson, Sherwin Rosen, Stewart Schwab and Steven Willborn all draw clear contrasts between Title VII and the ADA's mandate of "reasonable accommodations."126 Krieger's view is similar: "The ADA," she writes, incorporates "a profoundly different model of equality from that associated with traditional nondiscrimination statutes like Title VII," as the ADA requires that disabled individuals "in certain contexts . . . be treated differently, arguably better," than other workers. ${ }^{127}$ Again, these perspectives are hard to reconcile with the ways in which disparate impact liability under Title VII imposes accommodation requirements across the range of settings described in section II.A above.

The argument here is not that because Title VII's disparate impact branch tracks the "reasonable accommodations" provision of the ADA in requiring certain forms of accommodation, race and other traits covered by Title VII are therefore somehow "the same as" the trait of disability. Obviously there are differences across these contexts; the analogy to disability is certainly, as Mari Matsuda has written in discussing this issue, "inexact." 128 Nonetheless, seeing the relationships between the Title VII categories and disability is important for precisely the reason Matsuda notes: "[D]isability law confronts head-on the fact of difference among human beings and the benefit gained from accommodating those differences." ${ }^{129}$ My central point here is that traits covered by Title VII require - and in some cases in fact re-

Title VII. Id. at 3 I5 \& n.40. However, nothing in their discussion suggests that they see any distinction for this purpose between the education setting and the employment setting.

125 Id. at 315-16.

126 Rosen, supra note 7, at 21 ; Schwab \& Willborn, supra note 16 , at I-3, 28-29, 64 .

127 Krieger, supra note 16 , at 3-4.

128 Mari J. Matsuda, Voices of America: Accent, Antidiscrimination Law, and a Jurisprudence for the Last Reconstruction, IOO YALE L.J. I329, 138I (I99I).

129 Id. at I $38 \mathrm{I}-82$. 
ceive - accommodation through the operation of disparate impact liability.

2. The Domain of Disparate Impact Liability. - Karlan and Rutherglen, for their part, defend the sharp distinction they draw between antidiscrimination and accommodation by reference to the idea that "an underlying assumption of the disparate impact case law [under Title VII] is that it is the selection procedures, rather than the elements of the job itself as currently configured, that have caused the disparate impact." 130 They claim that the ADA's "reasonable accommodations" provision, by contrast, relates to restructuring the "elements of the job itself." ${ }^{131}$ This view, however, is inconsistent with the disparate impact case law under Title VII in contexts such as grooming, English-only rules, and pregnancy (all discussed in section II.A above); a rule requiring no facial hair, specifying the use of the English language, or prohibiting leave for medical conditions is plainly an "element of the job itself" rather than (or at least in addition to) a selection procedure. Disparate impact liability, like the ADA's "reasonable accommodations" provision, challenges the way in which the job is defined or structured in addition to the way in which candidates are selected for positions.

It might be urged in response to my argument that the disparate impact cases that have been successful at the Supreme Court level have all involved challenges to selection procedures rather than challenges to the "elements of the job itself." And selection procedures fall comfortably within the ambit of section 703(a)(2) of Title VII, which regulates discriminatory deprivation of employment opportunities, while challenges to the "elements of the job itself" fit more naturally under section $703(a)(I)$, which prohibits discrimination in the "terms, conditions, or privileges of employment." ${ }^{132}$ As just suggested, the Supreme Court has never had to decide whether disparate impact claims can arise under section 703(a)(I). But Congress's statutory codification of disparate impact liability in the Civil Rights Act of I99 I strongly supports the conclusion that this form of liability is available under section $703(\mathrm{a})(\mathrm{I})$ as well as under section $703(\mathrm{a})(2)$. The Act provides that "[a]n unlawful employment practice based on disparate impact is established" under specified conditions, ${ }^{133}$ and section 703(a) of Title VII defines the term "unlawful employment practice" as including both discrimination in the "terms, conditions, or privileges of employment" (section $703(\mathrm{a})(\mathrm{I}))$ and discriminatory deprivation of employment op-

\footnotetext{
130 Karlan \& Rutherglen, supra note 16, at 9 n.34 (second emphasis added).

131 Id. at 9.

13242 U.S.C. \& 2000e-2(a)(I), (2) (1994).

133 Id. $\$ 2000 \mathrm{e}-2(\mathrm{k})(\mathrm{I})(\mathrm{A})$ (emphasis added).
} 
portunities (section 703(a)(2)). ${ }^{134}$ Furthermore, numerous courts of appeals have held that disparate impact liability is available under section $703(\mathrm{a})(\mathrm{I})$ as well as section $703(\mathrm{a})(2) .{ }^{135}$ Still a further point is that some employment practices simply cannot be exclusively categorized as either selection procedures or "elements of the job itself." This was true, for example, of the no-beard policy in the Domino's case discussed in section II.A.I above; that rule was both a hiring criterion and a condition of the job once obtained. Similarly, one could easily imagine the requirement that officers be able to run 1.5 miles in twelve minutes in the Lanning case discussed above being applied periodically to current employees as well as to applicants (although in the actual case union protests led the employer to replace discipline for current employees' failure to meet the requirement with rewards for meeting $\left.\mathrm{it}^{136}\right)$. It is hard to see a reason for declaring a no-beard rule or other measure unlawful as a selection procedure but lawful as an "element of the job itself"; indeed, if anything, one would think that the current employee has the greater interest to be protected. Moreover, a limitation focused exclusively on selection procedures would seemingly be of little practical importance because a candidate, once hired, could presumably be fired for failing to meet the requirement. For all of these reasons, the distinction between selection procedures and "elements of the job itself" seems an untenable mechanism for limiting the scope of disparate impact liability, as well as a restriction that lacks support in existing doctrine.

All of this is not to say that altering selection procedures and altering the "elements of the job itself" are alike in every respect. Economic analysis of changes in job elements, for instance, differs from economic analysis of changes in selection criteria - a point to which I return in detail in section III.B.2 below.

3. The Importance of Disparate Impact Liability. - A further response to my claim that antidiscrimination and accommodation are overlapping rather than fundamentally distinct categories is the idea that disparate impact liability, which constitutes the site of the overlap, is only a marginal or unimportant feature of the antidiscrimination category. Krieger makes just this argument, as do Issacharoff and Nelson. ${ }^{137}$

A good way to think about this argument is to ask whether it would matter if the disparate impact form of liability were eliminated

134 Id. $\S 2000 \mathrm{e}-2(\mathrm{a})(\mathrm{I}),(2)$.

135 E.g., Garcia v. Spun Steak Co., 998 F.2d 1480, $4485-86$ (9th Cir. 1993); Colby v. J.C. Penney Co., 8 I I F.2d I I 19, II26-27 (7th Cir. 1987).

136 Lanning v. Southeastern Pa. Transp. Auth., I8I F.3d 478, 483 (3d Cir. I999), cert. denied, 528 U.S. I I 3 I (2000).

137 Issacharoff \& Nelson, supre note 16, at 317 n.49; Krieger, supra note 16, at 3 n.I 4 . 
from Title VII. Such a change would, roughly speaking, do to Title VII what Washington v. Davis ${ }^{138}$ did to the Equal Protection Clause of the Fourteenth Amendment. I think it is clear that it would matter a great deal if Title VII were altered in this way. Certainly Congress thought it would matter, as it quickly responded to a 1989 Supreme Court decision ${ }^{139}$ cutting back on (although not even eliminating) disparate impact liability by codifying this form of liability, and its contours, in the Civil Rights Act of I99r. ${ }^{140}$

Krieger defends her position by noting that the number of disparate impact claims is small compared to the total number of litigated Title VII claims. ${ }^{14 i}$ That is certainly correct, as John Donohue and Peter Siegelman have shown. ${ }^{142}$ But the simple number of disparate impact claims is not a good measure of their underlying importance - a point that Donohue and Siegelman were careful to note in their work. ${ }^{143}$ The number of disparate impact claims is not a reliable predictor of their actual importance for precisely the reasons - noted by Krieger herself - that these claims are limited in number: plaintiffs must identify general employment practices (such as the no-beard rule discussed above) that disproportionately harm a particular group, and they must present statistical evidence of such harm. ${ }^{144}$ That sort of case obviously has much broader potential impact than an individual disparate treatment case targeting a specific employment action taken against a particular individual. If a no-beard rule is struck down in a suit against a Domino's franchise, many other employers are likely to consider altering their grooming policies in response, whereas a finding of individual discriminatory behavior by a Domino's franchise would presumably have relatively little effect outside the Domino's franchise. Of course, some of the disparate treatment cases in Donohue and Siegelman's numbers may be systemic disparate treatment (or "pattern or practice") cases rather than individual disparate treatment actions, and these systematic disparate treatment cases may be more like disparate impact actions in the breadth of their effects; but given the small volume of Title VII class actions in Donohue and Siegelman's

\footnotetext{
138426 U.S, 229 (1976).

139 Wards Cove Packing Co. v. Atonio, 490 U.S. 642 (1989).

140 Pub. L. No. 102-166, \& 105(a), I05 Stat. 107r, 1074-75 (I99I) (codified at 42 U.S.C. $\S 2000 e-2(k)$ (I 994)).

141 Linda Hamilton Krieger, The Content of Our Categories: A Cognitive Bias Approach to Discrimination and Equal Employment Opportunity, 47 STAN. L. REV. II6I, II62 n.3 (I995), cited in Krieger, supra note 16 , at 3 n.I4.

142 John J. Donohue III \& Peter Siegelman, The Changing Nature of Employment Discrimination Litigation, 43 STAN. L. REV. 983 , 998 (I991).

143 See id. at 998 n.57.

144 Krieger, supra note 141 , at I 162 n.3.
} 
study, ${ }^{145}$ the number of systemic disparate treatment cases is likely to be quite small.

For all of the foregoing reasons, the argument that disparate impact liability is peripheral or unimportant to antidiscrimination law is unpersuasive. Even if one does not believe that disparate impact is at the absolute core of the antidiscrimination category, it is far from marginal. And although the grooming, English-only, and pregnancy examples discussed above may be special in various respects, the examples involving job selection criteria are absolutely central to disparate impact law. It follows, therefore, that the way in which disparate impact liability imposes accommodation requirements provides an important counterweight - not just a marginal objection - to the idea that antidiscrimination and accommodation are fundamentally distinct rather than overlapping categories.

\section{Implications for Section 5 of the Fourteenth Amendment}

The foregoing discussion has shown that certain applications of disparate impact liability under Title VII are in fact accommodation requirements. This section traces some implications of this argument for Congress's power under Section 5 of the Fourteenth Amendment to enact various federal employment laws. The starting point is the judicial precedent supporting the conclusion that disparate impact liability under Title VII is within Congress's Section 5 power. After describing that precedent, I will argue that legal rules that expressly mandate the provision of particular benefits to employees, but that have the same substantive scope as applications of disparate impact liability, should similarly be held to be within Congress's Section 5 power.

I. Judicial Precedent Upholding Disparate Impact Liability Under Title VII as Within Congress's Section 5 Power. - Because some aspects of disparate impact liability under Title VII are in fact accommodation requirements, this form of liability clearly goes beyond the prohibition of subtle or underlying forms of intentional discrimination, although, as described above, an important part of what it does is to catch such instances. How does the scope of disparate impact liability affect Congress's power under Section 5 to impose this form of liability? As noted previously, Section 5 is Congress's only source of power when authorizing private actors to sue state governments for money damages.

Section 5 empowers Congress to "enforce, by appropriate legislation,"146 the substantive provisions of the Fourteenth Amendment, including the Equal Protection Clause. The Equal Protection Clause it-

145 Donohue \& Siegelman, supra note 142 , at IoI9-2I.

146 U.S. CONST. amend. XIV, \& 5. 
self does not subject practices that create a disparate impact to any form of heightened scrutiny (although, as noted in Part I above, it does subject various forms of disparate treatment, or demonstrably intentional, discrimination to such scrutiny). ${ }^{147}$ However, this limitation of the Equal Protection Clause does not alone take Title VII's disparate impact branch outside of Congress's Section 5 power. The Equal Pay Act, ${ }^{148}$ for instance, is generally thought to go (somewhat) beyond what is prohibited by the Equal Protection Clause itself, ${ }^{149}$ and yet federal courts of appeals have repeatedly held that the Act is within Congress's Section 5 power. ${ }^{150}$

Similarly, in decisions spanning more than two decades, courts of appeals that have considered Congress's Section 5 power to impose disparate impact liability under Title VII have uniformly upheld it as within this power. ${ }^{151}$ The Supreme Court, for its part, has recently reaffirmed that "[l]egislation which deters or remedies constitutional violations can fall within the sweep of [Congress's] enforcement power even if in the process it prohibits conduct which is not itself unconstitutional." 152 "Congress is not limited to mere legislative repetition of this Court's constitutional jurisprudence."153 Legislation that deters or remedies constitutional violations is, in the words of Christopher Eisgruber and Lawrence Sager, "instrumentally useful" in preventing unconstitutional behavior. ${ }^{154}$ Acting against a sufficient backdrop of past instances of unconstitutional behavior, Congress may legislate so long as the legislation in question "exhibit[s] 'congruence and proportionality between the injury to be prevented or remedied and the means adopted to that end."'155 Applying the current Supreme Court framework, several recent lower federal court decisions have held that dis-

147 Washington v. Davis, 426 U.S. $229,239-48$ (I976).

14829 U.S.C. § 206 (d) (1994).

149 See, e.g., Varner v. Ill. State Univ., 226 F. 3 d $927,932-33$ (7th Cir. 2000), cert. denied, 12 I S. Ct. 224 I (200I); Anderson v. State Univ. of N.Y., 107 F. Supp. 2 d I58, I63 (N.D.N.Y. 2000).

150 See Siler-Khodr v. Univ, of Tex. Health Sci. Ctr. San Antonio, 26r F.3d 542, 550 (5th Cir. 200I) (citing cases).

151 Okruhlik v. Univ. of Ark., 255 F.3d 615, 624-27 (8th Cir, 2001); In re Employment Discrimination Litig. Against the State of Ala., I98 F.3d I305, I319-24 (1 1th Cir. I999); Liberles v. County of Cook, 709 F.2d II22, II 35 (7th Cir. I983); Scott v. City of Anniston, 597 F.2d 897, 899900 (5th Cir. 1979). The Seventh Circuit has expressly reserved the question whether Title VII's disparate impact branch is within Congress's power under the Supreme Court's recent Section 5 decisions. Erickson v. Bd. of Governors of State Colls. \& Univs. for Northeastern Ill. Univ., 207 F.3d 945, 952 (7th Cir. 2000), cert. denied, I 2 I S. Ct. II 87 (200I).

152 City of Boerne v. Flores, 52 I U.S. 507, 5 I 8 (I 997 ) (emphasis added).

153 Bd. of Trs. of the Univ. of Ala. v. Garrett, I 2 I S. Ct. 955, 963 (200I).

154 Christopher L. Eisgruber \& Lawrence G. Sager, Congressional Power and Religious Liberty After City of Boerne v. Flores, 1997 SUP. CT. REV. 79, 87-88.

155 Garrett, I2 I S. Ct. at 963, 964-66 (quoting City of Boerne, 52 I U.S. at 520 ). 
parate impact liability under Title VII is within Congress's Section 5 power. ${ }^{156}$

A prominent 1999 decision by the Eleventh Circuit in a race discrimination case, for instance, held that disparate impact liability was within the Section 5 power because "[a]lthough the plaintiff is never explicitly required to demonstrate discriminatory motive" in a disparate impact case under Title VII, a "finding of disparate impact can be highly probative of the employer's motive since a racial 'imbalance is often a telltale sign of purposeful discrimination,'" which in turn is subject to searching judicial review under the Equal Protection Clause. ${ }^{157}$ Thus, according to the Eleventh Circuit, a showing of forbidden disparate impact is related to the underlying constitutional violation of prohibited intentional discrimination even though Title VII's disparate impact branch undoubtedly sweeps more broadly in its coverage. ${ }^{158}$ This linkage between disparate impact liability and the underlying constitutional violation - viewed against the backdrop of "the troubling persistence of race discrimination in public employment," according to reports cited by the Congress enacting the relevant legislation - sufficed, according to the Eleventh Circuit, to sustain disparate impact liability as within Congress's Section 5 power. ${ }^{159}$ As the court emphasized, its reasoning was not to be read to say that in a disparate impact suit a "plaintiff must prove discriminatory intent . . . ; it is clear that what plaintiffs must demonstrate is a discriminatory result, coupled with a finding that the employer has no explanation as to why the challenged practice should be sustained as a job related business necessity."160

The Supreme Court itself has not yet addressed Congress's power under Section 5 to enact the disparate impact branch of Title VII. (Somewhat relatedly, the Court last Term in Alexander v. Sandoval 161 found it unnecessary to decide whether a disparate impact regulation was authorized by a congressional statute prohibiting intentional discrimination. ${ }^{162}$ ) Would the Supreme Court come out the same way as the lower court precedent on the question of Congress's Section 5 power to enact the disparate impact branch of Title VII? I do not attempt to provide a comprehensive answer to this question because my

156 Okruhlik, 255 F.3d at 624-27; In re Employment Discrimination Litig., I98 F.3d at 1319-24; Reynolds v. Ala. Dep't of Transp., 4 F. Supp. 2 d Iog2, Iog8-I I 2 (M.D. Ala. I 998 ).

157 In re Employment Discrimination Litig., 198 F.3d at $1319-2$ I (quoting International Brotherhood of Teamsters $v$. United States, 43 I U.S. 324, 339-40 n.20 (1977)).

158 Id. at $132 \mathrm{I}-22$.

159 Id. at $132 \mathrm{I}-24$.

160 Id. at 1322 (emphasis added).

161 I2I S. Ct. I5II (200I).

162 Id. at 1515,1516 . The statute in question was $\$ 601$ of Title VI of the Civil Rights Act of I 964,42 U.S.C. $\$ 2000 d$ (I994). 
central point here is instead the relationship between Congress's Section 5 power to impose disparate impact liability under Title VII and its power to impose legal rules that expressly mandate the provision of particular benefits to employees; however, a few points are worth noting briefly here alongside the substantial commentary that already exists on the question of Congress's Section 5 power to impose disparate impact liability under Title VII. ${ }^{163}$

First, as described above, some members of the Supreme Court showed an inclination, prior to the Civil Rights Act of r99I, toward a narrow conception of disparate impact liability, stemming from a deferential standard of business necessity. ${ }^{164}$ Such an approach would certainly make disparate impact liability easier to uphold as within Congress's power under Section 5 , but it would also mean that disparate impact liability was less apt to impose requirements of accommodation. However, the Civil Rights Act of I99I makes clear that the business necessity standard is more substantial, as described above. ${ }^{165}$ The Court's possible distaste for this broader view might suggest that it would be reluctant to find it within Congress's power under Section 5 , for, if the Court is stuck with Congress's conception of disparate impact liability as a general matter, at least it can still be the final arbiter of whether this conception may be applied in suits against state governments for money damages.

A second and countervailing point, though, is that the robust conception of disparate impact liability embraced by Congress in the Civil Rights Act of I99I plays an important role in ferreting out subtle forms of intentional discrimination and, therefore, is connected to the prevention and remediation of violations of the underlying substantive constitutional prohibition on intentional discrimination. A robust conception of disparate impact liability plays such an important role in ferreting out subtle instances of intentional discrimination because, as described in section II.A above, there is simply no easy, neat way of separating out subtle instances of intentional discrimination from other behavior, and therefore a robust conception of disparate impact liability is needed to police underlying intentional discrimination effectively. To be sure, a narrow conception of disparate impact liability, achieved through a deferential standard of business necessity, would guarantee that few or no findings of liability would be made in the absence of intentional discrimination, but it would do so only at the cost of leaving

163 See, e.g., Eisgruber \& Sager, supra note 154, at 90-92; Daniel J. Meltzer, Congress, Courts, and Constitutional Remedies, 86 GEO. L.J. 2537, 2547-48 (r998); Robert C. Post \& Reva B. Siegel, Equal Protection by Law: Federal Antidiscrimination Legislation After Morrison and $\mathrm{Ki}-$ mel, I IO YALE L.J. 44I, 467-73 (2000).

164 See cases cited supra notes I08-I I 3 and accompanying text.

165 See sources cited supra notes II5-I I 8 and accompanying text. 
additional cases of intentional discrimination undetected. This is so because it is entirely obvious that employers would often be able to come up with some sort of legitimate business ground for their practices even when their motives are in fact discriminatory. Only by ratcheting up the standard of justification to a robust notion of business necessity can the system catch a larger fraction of the instances of true underlying intentional discrimination.

The Eleventh Circuit decision discussed above alternately brackets and reflects the competing considerations just described, and also the ambivalence that, as discussed earlier, Siegel detected in the seminal disparate impact case, Griggs v. Duke Power Co. For instance, at one point in the Eleventh Circuit's opinion, the court seemed to suggest an almost airtight link between disparate impact liability and intentional discrimination (although it pulled back with the insertion of "probably" at the end): "If, after a prima facie demonstration of discriminatory impact, the employer cannot demonstrate that the challenged practice is a job related business necessity, what explanation can there be for the employer's continued use of the discriminatory practice other than that some invidious purpose is probably at work?"166 As Siegel and Robert Post note, if this attempt by the court to "reconcile" the disparate impact and intentional discrimination standards "were taken seriously, it would suggest a fundamental reworking of an important area of Title VII jurisprudence."167 But Post and Siegel go on to note that "it is not at all clear that the Eleventh Circuit meant for its own conclusion to be taken seriously, for the court goes out of its way to emphasize the view that disparate impact doctrine can be applied to the states without alteration."168 The Eleventh Circuit couched its ultimate conclusion in language that seems to try to mediate between the conflicting conceptions it was juggling: "[T]he core" (and thus not the exclusive) "injury targeted by" (and thus not necessarily coterminous with) disparate impact liability is "intentional discrimination," and thus "the disparate impact provisions of Title VII can reasonably be characterized as 'preventive rules' that evidence a 'congruence between the means used and the ends to be achieved.'"169

The important point for my purposes here is that the Eleventh Circuit's holding, like those of the other decisions cited earlier, sustains Congress's power under Section 5 to impose the disparate impact branch of Title VII with, as Post and Siegel note, no suggestion that

166 In re Employment Discrimination Litig. Against the State of Ala., I98 F.3d I305, I32 I-22 (i ith Cir. I 999 ) (emphasis added).

167 Post \& Siegel, supra note 163 , at $45^{2}$.

168 Id. at $45^{2}$ n.5 I.

169 In re Employment Discrimination Litig., 198 F.3d at 1322 (emphasis added) (quoting City of Boerne v. Flores, 52 I U.S. 507,530 (1997)). 
disparate impact liability differs from its usual scope when suits for money damages are brought against the states. ${ }^{170}$ As already noted, my central goal here is not to provide a normative or doctrinal defense of this result (a task that others have taken up ${ }^{171}$ ), but simply to describe the state of existing doctrine in the lower federal courts. The next section traces some implications for laws that, like disparate impact liability, operate to require accommodation in some instances, but do so more directly by expressly mandating the provision of particular benefits to employees.

2. Implications for the FMLA and Other Express Mandates. - As just described, existing doctrine holds Title VII's disparate impact branch to be within Congress's power under Section 5 despite the fact that disparate impact liability sweeps more broadly than the prohibition on intentional discrimination contained in the Equal Protection Clause itself. What does this conclusion imply for Congress's power under Section 5 to enact legal rules that expressly mandate the provision of particular benefits to employees - in other words, rules that, unlike disparate impact liability, carry their "accommodationist" aspects transparently on their face?

Consider a concrete example. Recall that prohibitions on speaking languages other than English in the workplace may create an unlawful disparate impact on the basis of national origin. Suppose that Congress, concerned about the problem of English-only policies in the workplace and eager to legislate directly on the issue rather than relying on the less transparent route of disparate impact liability under Tithe VII, passes a law - similar to one recently passed at the state level by California ${ }^{172}$ - requiring employers to allow employees with limited or no English proficiency to use their native language in conversations with coworkers unless an English-only rule can be shown to be a "business necessity." This is the same substantive standard as under Title VII, for, as described above, English-only policies automatically cause disproportionate harm based on national origin when applied to employees with limited or no English proficiency (and thus the only remaining issue for disparate impact liability is whether an employer can show business necessity). ${ }^{173}$

The substantive standard set forth in Title VII and shared by the hypothetical law will help to catch some instances of underlying intentional discrimination, as mentioned above and as suggested by the facts of reported cases such as EEOC v. Premier Operator Services,

170 Post \& Siegel, supra note 163 , at 452 n.5 I.

171 E.g., id. at $467-73$; Eisgruber \& Sager, supra note I 54, at 90-92.

172 200I Cal. Legis. Serv. 295 (A.B. 800) (West).

173 See EEOC v. Synchro-Start Prods., Inc., 29 F. Supp. 2d 911 , $912-13$ (N.D. Ill. 1999). 
Inc. ${ }^{174}$ (in which an English-only policy was imposed by a company whose president also made repeated ethnic slurs ${ }^{175}$ ) and Saucedo $v$. Brothers Well Service, Inc. ${ }^{176}$ (in which a prohibition on speaking Spanish was instituted at a company that also employed a foreman who engaged in "manifest racial discrimination"177). But, as described in section II.A.3 above, a substantive rule such as this also sweeps in other instances (ones in which there is no intentional discrimination), and in this respect it is an accommodation requirement, for it forces employers to bear genuine business costs wholly apart from any intent on their part to treat employees differently based on their national origin. The mix of ferreting out intentional discrimination and imposing accommodation requirements is the same with disparate impact liability under Title VII and with the hypothetical law, as the substantive standards are the same in both cases. It follows that if there is a sufficiently close relationship, for Section 5 purposes, between disparate impact liability under Title VII and the prevention or remediation of unconstitutional intentional discrimination - as the lower court precedent discussed above suggests there is - then there must be a sufficiently close relationship, for Section 5 purposes, between the hypothetical law and the prevention or remediation of unconstitutional intentional discrimination. Surely courts should not be fooled by the form in which a law appears.

As suggested briefly above, a separate aspect of the determination whether legislation is within Congress's power under Section 5 involves an inquiry (whose precise status is unclear under recent Supreme Court precedent) into whether Congress acted against a sufficient backdrop of past instances of unconstitutional behavior. ${ }^{178}$ The backdrop issue is interesting here because of the difference in the enactment dates of the two laws under consideration - Title VII's disparate impact branch, which became applicable to states with the en-

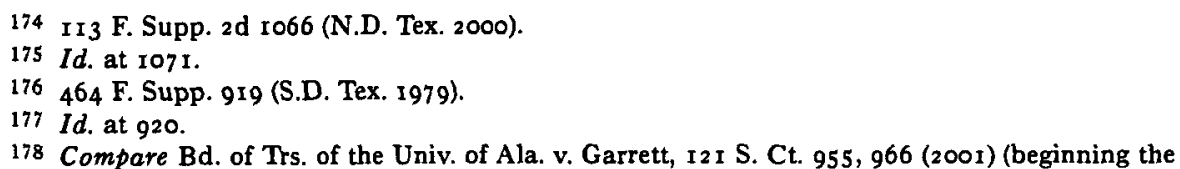
Section 5 analysis by noting the absence of a sufficient backdrop of past instances of unconstitutional behavior, and only then stating that "even were it possible" to find such a backdrop, the scope of the requirements imposed by the legislation in question "would raise . . concerns" on account of their breadth in relation to the underlying substantive constitutional prohibition (emphasis added)), with Kimel v. Fla. Bd. of Regents, 528 U.S. 62, 82-91 (2000) (concluding first that the legislation in question had far broader scope than the relevant substantive constitutional prohibition, and then proceeding to examine the record before Congress to discern whether that record might nonetheless provide a basis for the legislation by showing a backdrop of past instances of unconstitutional behavior, and finally stating that such a lack of support in the legislative record "is not determinative of the $\S 5$ inquiry"). 
actment of the Equal Employment Opportunity Act of 1972,179 and the hypothetical law, enacted, we suppose, today. Obviously, the backdrops of the two laws might be quite different.

Even more intriguing timing questions - now linking back to the issue of the relationship between the legislation in question and the underlying substantive constitutional prohibition - arise from the fact that the practice of relying on facially neutral policies to engage in subtle forms of intentional discrimination may well have become less common over time. (Note that this practice may also be more or less common in the context of different protected traits such as race or sex.) This change over time is of significance here because the practice of relying on facially neutral policies to engage in subtle forms of intentional discrimination is precisely what provides the link between the challenged legislation and the underlying substantive constitutional prohibition. If (and this is an important if) legislation is always assessed, for Section 5 purposes, based on the circumstances existing at the time of its enactment, then it is possible that Title VII's disparate impact branch has a sufficiently close link, for Section 5 purposes, to the underlying substantive constitutional prohibition, while the hypothetical law with identical substantive scope enacted today would not. The oddness of that result may suggest that legislation should be assessed on an ongoing basis rather than simply in light of the circumstances existing at the time of its enactment. ${ }^{180}$

All of these points have important implications for resolution of the recurring question in the courts of Congress's Section 5 power to enact the Family and Medical Leave Act. As noted above, the FMLA requires employers to provide unpaid leave in the event of, among other things, medical conditions that render employees unable to perform their job functions. ${ }^{181}$ Most of the FMLA cases raising a Section 5 issue have involved this provision of the Act. ${ }^{182}$

The medical leave provision of the FMLA is openly "accommodationist"; it expressly requires that a particular benefit be provided to employees. Numerous courts have emphasized this point in concluding that the provision is not within Congress's Section 5 power. ${ }^{183}$ As one court reasoned, "[T]he FMLA ... creates an affirmative obligation

179 Pub. L. No. 92-26 I, 86 Stat. 103 (1972).

180 For related discussion, see Meltzer, supra note 163 , at 2548 n.70.

18129 U.S.C. $\$ 26 \mathrm{I} 2(\mathrm{a})(\mathrm{I})(\mathrm{D})(\mathrm{r} 994)$.

182 See Laro v. New Hampshire, 259 F.3d I, 17 (Ist Cir, 200I) (listing cases). Kazmier v. Widmann, 225 F.3d 5 I 9 (5th Cir. 2000), a Section 5 case, involved both the medical leave provision and a separate provision of the FMLA requiring employers to provide leave to employees who wish to care for ill family members.

183 See Lizzi v. Alexander, 255 F.3d I28, I35 (4th Cir. 200I); Chittister v. Dep't of Cmty. \& Econ. Dev., 226 F.3d 223, 229 (3rd Cir. 2000); Sims v. Univ. of Cincinnati, 2 19 F.3d 559, 565 (6th Cir. 2000); Hale v. Mann, 2 Ig F.3d 61, 69 (2d Cir. 2000). 
on the part of the States to provide twelve weeks of leave. Nothing in the Equal Protection Clause, of course, creates such an obligation."184

What these courts have not noticed, however, is that the substantive scope of the FMLA provision is quite similar to that of disparate impact liability under Title VII - which, in turn, has repeatedly been upheld as within Congress's Section 5 power, as noted above. As described in section II.A.4 above, a number of courts have held that Title VII's disparate impact branch makes unlawful some facially neutral employer policies disallowing leave for medical conditions, including pregnancy, because of the policies' disproportionate harm to female employees. ${ }^{185}$ Assuming that the remedy in such circumstances is general invalidation of the challenged policy - the usual remedy in a disparate impact case ${ }^{186}$ - the ultimate effect of the application of disparate impact liability is that the employer is required to offer medical leave to its employees. Of course, this is precisely what is required by the FMLA. Thus, just as in the English-only example above, an openly "accommodationist" law turns out to have a substantive scope quite similar to that of disparate impact liability. Note also that protection of female employees suffering from pregnancy-related medical conditions was clearly in Congress's mind in passing the medical leave provision of the FMLA, as the purposes section of the Act specifically refers to the goal of ensuring the availability of leave for "eligible medical reasons (including maternity-related disability)."187

The substantive scope of the FMLA's medical leave provision is actually somewhat broader than that of disparate impact liability because, as described above, disparate impact liability in the leave context requires a showing that a facially neutral policy disallowing leave disproportionately harms female employees. ${ }^{188}$ The FMLA provision, by contrast, in effect presumes such disproportionate harm. The FMLA provision also lacks a "business necessity" defense for employers, although it does contain certain other defenses. ${ }^{189}$ Nonetheless, the parallels between the FMLA provision and disparate impact liability are sufficiently strong that opposing conclusions about Congress's power under Section 5 to enact them may be unwarranted.

184 Sims, 2 I9 F.3d at 565 (emphasis added).

185 See EEOC v. Warshawsky \& Co., 768 F. Supp. 647, 651-55 (N.D. Ill. 199I); cases cited supra note 83 .

186 See, e.g., Williams, supra note 56 , at 368 .

18729 U.S.C. $\$ 260 \mathrm{r}(\mathrm{b})(4)$ ( 1994$)$ (emphasis added). The separate provision of the FMLA requiring leave after the birth of a child, id. $\$ 26 \mathrm{I}_{2}(\mathrm{a})(\mathrm{I})(\mathrm{A})$, does not relate to pregnancy-related medical conditions at all because the leave is specifically described as for the purpose of "car[ing] for" the newborn child. Thus, this provision is not discussed here.

188 See, e.g., Warshawsky, 768 F. Supp. at $65 \mathrm{I}-54$.

189 See 29 U.S.C. $\& 26 \mathrm{I}_{4}(\mathrm{a})(3)$, (b). 
This suggestion, and its implicit idea that the FMLA provision may be within Congress's power under Section 5, require some further fleshing out in light of the unanimous conclusion of the federal courts of appeals that the FMLA provision is not within Congress's Section 5 power. ${ }^{190}$ One important threshold question is whether the specific application of Title VII disparate impact liability to employer policies that disallow leave for medical conditions is within Congress's Section 5 power (even if Title VII disparate impact liability in general is within that power). Although a number of the cases addressing Congress's Section 5 power to enact Title VII's disparate impact branch have arisen in the race context, the Eighth Circuit has addressed the question in the specific context of disparate impact liability on the basis of sex. ${ }^{191}$ According to the Eighth Circuit, Title VII's "prophylactic ban on disparate impact discrimination" on the basis of sex is sufficiently closely related, for Section 5 purposes, to the goal of preventing "unconstitutional intentional discrimination."192 Moreover, in the view of the Eighth Circuit, the demonstrated backdrop of past instances of discriminatory behavior at the time Congress enacted the Equal Employment Opportunity Act of 1972, while somewhat limited, was nonetheless adequate because "Supreme Court jurisprudence has indicated that '[a]fter Congress has legislated repeatedly in an area ... that may reduce the need for fresh hearings and prolonged debates'... [, and] [a]t the same time Congress was passing the 1972 Act, it was also considering the Equal Rights Amendment," in connection with which it held "extensive hearings and received numerous reports detailing" sex discrimination by the states. ${ }^{19.3}$ Parallel to the Eighth Circuit decision, courts addressing Congress's Section 5 power to enact the Equal Pay Act (which, as noted above, is similar to disparate impact liability in that it has a scope different from that of the underlying substantive constitutional prohibition) have unanimously upheld the Act notwithstanding the limits of the record before Congress as to the backdrop of past instances of unconstitutional behavior. ${ }^{194}$

But disparate impact liability in the particular context of employer leave policies, as opposed to the context of sex discrimination generally, raises special issues; this is so because the link between the employer practice and sex discrimination is mediated by the condition of preg-

\footnotetext{
190 See Laro v. New Hampshire, 259 F.3d I, 16-17 (Ist Cir. 200I) (citing cases).

191 See Okruhlik v. Univ. of Minn., 255 F.3d 615, 624-27 (8th Cir. 2001).

192 Id. at 626-27 (citing In re Employment Discrimination Litigation Against the State of Alabama, I 98 F.3 I I 305, I32 1-24 (1 Ith Cir. I999)) (internal quotation marks omitted).

193 Id. at 625-26 (quoting Fullilove v. Klutznick, 448 U.S. 448, 503 (1980) (Powell, J., concurring)).

194 See, e.g., Siler-Khodr v. Univ. of Tex. Health Sci. Ctr., 26 I F.3d 542, 550-5 I (5th Cir. 200I) (discussing cases addressing the record before Congress of past instances of unconstitutional behavior).
} 
nancy - a fact that has constitutional importance because distinctions based on pregnancy, unlike distinctions based on sex, do not give rise to heightened scrutiny under the Equal Protection Clause. ${ }^{195}$ The absence of heightened scrutiny means that most distinctions based on pregnancy are constitutional, and it therefore follows that a law would be difficult to uphold under Section 5 on the ground that it prevented or remedied unconstitutional discrimination against pregnant employees. Indeed, precisely this sort of reasoning underlies the Supreme Court's conclusion in Board of Trustees of the University of Alabamav. Garrett ${ }^{196}$ that Title I of the Americans with Disabilities Act is beyond Congress's Section 5 power, for distinctions based on disability, like distinctions based on pregnancy, do not give rise to heightened constitutional scrutiny. ${ }^{197}$ The Garrett Court, after concluding that states were not behaving unconstitutionally as "long as their actions toward [individuals with disabilities] are rational," readily concluded that " $t$ the legislative record of the ADA ... fails to show that Congress did in fact identify a pattern of irrational state discrimination in employment against the disabled," and that, in any event, the ADA's provisions swept far more broadly than the (limited) scope of the underlying substantive constitutional prohibition. ${ }^{198}$

As noted above, however, distinctions based on sex do give rise to heightened scrutiny, and thus discrimination on the basis of sex, as distinguished from discrimination on the basis of pregnancy, is often unconstitutional. As Judge Kermit Lipez has put it, "[ $t]$ he universe of constitutional governmental conduct based on gender is small," and thus congressional legislation "designed to prevent gender discrimination presumptively captures a wider range of unconstitutional conduct than" congressional legislation designed to prevent discrimination on the basis of a trait (such as pregnancy) that receives no heightened scrutiny. ${ }^{199}$ The critical question for Title VII disparate impact liability as applied to employer leave policies is therefore whether such policies can constitute a subtle means of effectuating intentional discrimination against female (as opposed to pregnant) employees. An affirmative answer seems quite reasonable, as pregnancy is a very common reason for needing medical leave and is, of course, exclusively a female occurrence. Thus, just as English-only rules may be a backdoor means of intentionally discriminating on the basis of national ori-

195 See United States v. Virginia, 5 I 8 U.S. 515, 53I-34 (I996) (sex-based distinctions receive heightened scrutiny); Geduldig v. Aiello, $4 \mathrm{I} 7$ U.S. 484, 494-95 (1974) (pregnancy-based distinctions do not receive heightened scrutiny).

196 I 2 I S. Ct. 955 (200I).

197 Id. at 963-64; Cleburne v. Cleburne Living Ctr., Inc., 473 U.S. 432, 442-47 (I 985).

198 Garrett, I2 I S. Ct. at 964-65 (emphasis added).

199 Laro v. New Hampshire, 259 F.3d I, 19-20 (Ist Cir. 200I) (Lipez, J., dissenting). 
gin (as described above), so too no-leave policies may be a backdoor means of intentionally discriminating against female employees. Indeed, perhaps Congress recognized this connection between policies disallowing leave and discrimination on the basis of sex when it provided that one of the purposes of the FMLA was to "promote the goal of equal employment opportunity for women and men, pursuant to [the Equal Protection Clause]."200

Apart from the threshold matter of Title VII disparate impact liability under Section 5, a second set of questions related to Congress's Section 5 power to enact the FMLA medical leave provision involves the two timing issues noted in connection with the English-only discussion above. Taking the two issues in reverse order, the first point is that (simply to repeat what was said above) the practice of relying on facially neutral policies to engage in subtle forms of intentional discrimination may have become less common by the time the FMLA was enacted than it was when the Equal Employment Opportunity Act (EEOA) was passed in I972. As relevant here, the critical questions are to what degree did states in the pre-enactment period of the FMLA decline to provide medical leave, and how likely is it that such decisions were influenced at least in part by a desire to discourage too high a level of employment of women of childbearing age, based perhaps on stereotypes about the capabilities and commitment levels of such employees?

On the other timing issue, the inquiry concerns the existence of a demonstrated backdrop of unconstitutional sex discrimination at the time the EEOA was enacted versus the existence of such a backdrop at the time the FMLA was enacted. There is an important conceptual point to be made here. Although there was (presumably) less sex discrimination in the period leading up to the FMLA's passage in I993 than in the pre-1972 period preceding the enactment of the EEOA and thus one would accordingly think that the FMLA provision would be harder to uphold than the EEOA - the degree to which such sex discrimination was actually unconstitutional was far greater in the pre-FMLA period than in the pre-I 972 period. This is so because in the pre-1972 period distinctions based on sex did not receive any form of heightened scrutiny. ${ }^{201}$ The lack of heightened scrutiny means that many distinctions based on sex presumably were constitutional. Thus, ironically, there is at least one respect in which the FMLA provision may actually be easier to uphold as within Congress's Section 5 power than disparate impact liability on the basis of sex under Title VII.

20029 U.S.C. $\$ 260$ r(b)(5) (1994).

201 See Reed v. Reed, 404 U.S. 7 I, 76 (1971). 
The argument here has not, of course, settled definitively the question whether the FMLA's medical leave provision is within Congress's Section 5 power. Not addressed at all here are the specific details of the evidentiary record before Congress as to unconstitutional sex discrimination in the period preceding the enactment of the FMLA. My point has simply been that the FMLA's medical leave provision has a substantive scope similar to that of the applications of disparate impact liability described in section II.A.4 above, and thus that existing precedent finding disparate impact liability to be within Congress's Section 5 power supports the conclusion that the FMLA provision is likewise within that power.

\section{AdDItional PARALlels BetWEen ANTIDISCRIMINATION AND ACCOMMODATION}

Certain aspects of disparate impact liability under antidiscrimination law are in fact accommodation requirements, as described above. This is not a normative claim in any respect; it is simply a factual claim that antidiscrimination and accommodation are identical in the specified instances.

In other cases, antidiscrimination and accommodation are not identical, but nonetheless they share fundamental parallels. Even those aspects of antidiscrimination law that prohibit intentional discrimination, and thus cannot qualify as accommodation requirements, share important and previously unrecognized similarities with accommodation requirements. In terms of the divide between disparate treatment and disparate impact discrimination, such prohibitions on intentional discrimination straddle the two categories; when intent can actually be demonstrated, prohibitions on intentional discrimination may be accomplished through disparate treatment liability, and when intent exists but cannot be proven, they may be accomplished through disparate impact liability.

The claim at this point is not that there is no normative difference at all between prohibitions on intentional discrimination (whether achieved through disparate treatment or disparate impact liability) and requirements of accommodation, just that they share certain normative similarities. Intentional discrimination might be thought to be meaningfully different as a category from the failure to accommodate because the two types of behavior are distinguished precisely by the presence of intentional differential treatment on the basis of group membership in the first case. The distinction based on the presence or absence of such intentional differential treatment may not be a sound one, but the point of what follows is not to question it. Thus I do not here claim a general or overarching normative equivalence between antidiscrimination and accommodation, although section III.C below briefly describes some existing arguments in the literature in support of 
this view. Instead, my focus is on the narrower point that prohibitions on intentional discrimination and requirements of accommodation share certain important similarities that have not been understood in the existing literature.

Given the discussion just above of the scope of Congress's power under Section 5 of the Fourteenth Amendment, a natural question here is whether the similarities described below between prohibitions on intentional discrimination and requirements of accommodation provide any basis for concluding that accommodation requirements are sufficiently related to the prohibition on intentional discrimination contained in the Equal Protection Clause itself to provide a new argument for upholding accommodation requirements as within Congress's Section 5 power. The answer to this question would seem to be "no," for while, as described above, courts have held that disparate impact liability is within Congress's Section 5 power notwithstanding its "accommodationist" aspects, the cost-based parallels described below between prohibiting intentional discrimination and requiring accommodation do not appear to be doing any work in support of this conclusion. Thus, the parallels described below are offered not because they bear upon the power of Congress to impose accommodation requirements under Section 5 but because of their conceptual and analytic significance.

Prohibitions on intentional discrimination embrace employer behavior based on several causal factors: (I) employer animus toward a particular group; (2) customer or coworker animus toward the group; (3) correct employer beliefs that group members are lower quality or higher cost employees on average; and (4) incorrect employer beliefs that group members are lower quality or higher cost employees on average. ${ }^{202}$ The third and fourth categories of behavior are commonly referred to as "statistical discrimination." 203 When employer beliefs are correct, such statistical discrimination is "rational." 204

As a way of introducing the discussion to follow, I begin with a point that will be familiar to some readers. The point is the way in which prohibitions on discrimination based upon customer or coworker attitudes or upon correct employer beliefs about a particular

202 E.g., David A. Strauss, The Law and Economics of Racial Discrimination in Employment: The Case for Numerical Standards, 79 GEO. L.J. I619, I623 \& n.13 (1991).

203 See, e.g., David Charny \& G. Mitu Gulati, Efficiency Wages, Toumaments, and Discrimination: A Theory of Employment Discrimination Law for "High-Level" Jobs, 33 HARV. C.R.-C.L. L. REV. 57, 63-66 (1998).

204 See id. at 63-64. As Charny and Gulati note earlier in their article, the general concept of animus discrimination, reflected in the first two categories listed in the text, is an oversimplification, but, as was true for Charny and Gulati, it captures the essential features necessary for my analysis. See id. at 62 n.I g. 
group impose financial costs on employers, much as do accommodation requirements. After briefly making that familiar point, I describe a more general set of cost-based parallels between prohibitions on intentional discrimination and requirements of accommodation.

\section{A. Customer/Coworker Discrimination and Rational Statistical Discrimination (Briefly)}

The familiar observation about discrimination based upon customer or coworker attitudes or upon correct employer beliefs about a particular group - an observation that bears repeating here because of its relationship to the analysis offered in Part II above - is that prohibitions on these types of discrimination require employers to incur real financial costs in connection with the employment of certain groups. ${ }^{205}$ In this respect such prohibitions on intentional discrimination are similar to requirements of accommodation.

Consider first prohibitions on discrimination based on customer or coworker attitudes. For instance, Title VII forbids employers to refuse to hire female candidates to work with particular customers even though those customers would be highly reluctant to work with a woman. ${ }^{206}$ Such prohibitions target not employers who themselves exhibit animus toward a particular group of employees but rather employers who engage in purely profit-maximizing economic behavior just as employers who refuse to incur additional costs to provide physical or other accommodations to particular employees are often engaging in such behavior. In the context of discrimination based on customer or coworker attitudes, antidiscrimination law is similar to an accommodation requirement in forcing employers to employ certain individuals even though they impose greater financial costs. These costs come in the form of lost business or reduced prices (for customer animus) and reduced productivity or higher wages (for coworker animus). Note that these costs will tend to be less, but nonetheless positive in the typical case, if antidiscrimination law applies to a firm's competitors as well as to the firm itself.

Precisely the same set of points can be made about rational statistical discrimination. Consider the example of pregnancy. An employer may be reluctant to hire a pregnant applicant not because of any animus toward pregnant women or women in general but simply because on average the pregnant applicant may be more costly to employ. If in fact such an applicant is more costly to employ, and if in fact the cost difference is the motivation for the employer's behavior, then prohibiting this behavior - like requiring accommodation - targets actions

205 See, e.g., Bagenstos, supra note 17 , at 456-57.

206 Fernandez v. Wynn Oil Co., 653 F.2d 1273, 1276-77 (9th Cir. 1981). 
based purely on grounds of profit maximization. The law forces employers to employ certain individuals even though they impose added costs. In the case of statistical discrimination, the added costs stem from the reduction in employee quality or the increase in direct outlays that results. Again, the ultimate effect of the law is to force the employer to bear costs in connection with the employment of a particular group wholly apart from any animus on the part of the employer toward that group.

That prohibitions on various forms of intentional discrimination impose real costs on employers cannot be seriously disputed. This understanding makes clear that such prohibitions do not reflect an ideal of forcing only "economic rationality" out of employers. Indeed such an ideal would have, in the words of Senator Clifford Case, a floor manager of Title VII, "destroy[ed] the bill" as a result of the prevalence of discriminatory customer and coworker attitudes at the time of Title VII's enactment. 207

Once it is recognized that even prohibitions on intentional discrimination impose real financial costs on employers, it is clear that such prohibitions share important similarities with accommodation requirements. So when it is asserted, for example, that requiring "individuals who are fundamentally the same" to be "treat[ed] ... identically" under antidiscrimination law means that an employer must ignore "irrelevant" characteristics ${ }^{208}$ - including those that have the effect of turning away customers or coworkers ${ }^{209}$ - it is worth asking why, or in what sense, these characteristics are in fact "irrelevant" if they affect the employer's profitability. Or, if they are "irrelevant," then why are not other characteristics that affect the employer's profitability, such as conditions that require the purchase of special equipment or the provision of special leave time, also "irrelevant" in the sense used here, as they create costs for employers and are beyond the individual employee's control? How can it be said that Title VII does not allow employees to "insist upon discrimination in their favor"210 when, as just described, even its prohibitions on intentional discrimination indisputably operate to require employers to bear extra costs in connection with the employment of particular groups? ${ }^{211}$

207 See George Rutherglen, Sexual Equality in Fringe-Benefit Plans, 65 VA. L. REV. I99, 249 (1979).

208 Karlan \& Rutherglen, supre note 16 , at ro.

209 Id.

210 Id. at 3 (emphasis added).

211 For an attempt to answer these questions about the validity of distinctions between prohibitions on intentional discrimination and requirements of accommodation, see Mark Kelman, Market Discrimination and Groups, 53 STAN. L. REV. 833, 840-55 (2001). 


\section{B. Effects of Antidiscrimination and Accommodation on Wages and Employment Levels}

In addition to the familiar parallel just noted between prohibitions on intentional discrimination and requirements of accommodation, there is yet another similarity between them. As described below, the two forms of legal intervention have parallel effects on wages and employment levels. In developing this commonality, I build upon a framework for analyzing accommodation requirements that I developed in a prior article. ${ }^{212}$

The first section below presents the basics of the analytic framework. The second section explains how the framework for accommodation requirements applies to prohibitions on intentional discrimination and thus illustrates the similarity of the two forms of legal intervention. The third section highlights an important result of applying the framework to prohibitions on intentional discrimination and other aspects of antidiscrimination law.

Apart from showing that prohibitions on intentional discrimination and requirements of accommodation share previously unrecognized parallels, the analysis in this section is of independent interest in showing how antidiscrimination law should be analyzed within a supply and demand framework. In this respect the analysis builds upon and extends Donohue's important work in this area. ${ }^{213}$

A threshold point is important here. Because antidiscrimination law is commonly viewed as rooted in claims of rights rather than economics, it may upon first glance seem unnatural to examine it within a supply and demand framework. But the unavoidable fact is that, as the discussion below will highlight, antidiscrimination law, like an accommodation requirement, creates costs for employers, even apart from the special situations (such as discriminatory customer or coworker attitudes) discussed above. In a market economy, employers remain free to respond to those costs of legal intervention by adjusting wages and employment levels - except insofar as effectively constrained from doing so by the law. Because of the costs created by antidiscrimination law, and because the law operates against the backdrop of employment markets, it is critical to examine antidiscrimination law from an economic perspective alongside the many other perspectives that have been offered on it.

I. Analytic Framework. - (a) The Existing Model. - The basic building block for analysis of the wage and employment effects of legal intervention, including the intervention accomplished by antidiscrimination law, is a diagram depicting labor supply and labor demand for

212 Christine Jolls, Accommodation Mandates, 53 STAN. L. REV. $223,230-72$ (2000).

213 Donohue, supra note 19 , at I415-30. 
a given group of employees, as shown in Figure $\mathrm{I}$. The supply of labor, represented by the upward-sloping curve labeled $S$, reflects these employees' willingness to work at different wage levels. The demand for labor, represented by the downward-sloping curve labeled D, reflects employers' demand for worker-hours at different wage levels based on the "marginal revenue product of labor," or amount of revenue generated by a given worker-hour. The intersection of the supply and demand curves gives the equilibrium wage $(W)$ and employment level (E) for the group of employees, as shown in Figure I. This figure provides the framework for existing market analyses of antidiscrimination law, including the well-known work of Donohue. ${ }^{214}$

\section{FIGURE I. SUPPLY AND DEMAND FRAMEWORK}

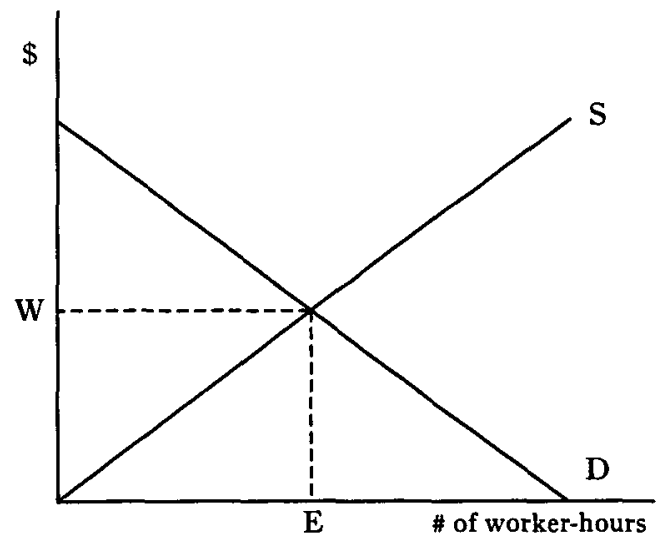

(b) A Modified Approach. - As Donohue has noted, the currently prevailing supply and demand approach to antidiscrimination law is incomplete in the sense that it focuses on a single employment market such as the one depicted in Figure I. "A more complete analysis should consider the effects of [antidiscrimination law] . . . on the [separate] market for white workers as well as on the market for black workers."215 In other words, it is not enough to focus just on a single market, such as the market for the group of employees who suffer from discrimination. It is important also to consider the market for the employees who do not suffer from discrimination, as the two markets are obviously closely related.

My analysis offers such a multi-market approach. It does so by drawing upon the supply and demand analysis of accommodation re-

215 Id. at 1427 n.39. 
quirements, for precisely the same concern with focusing on a single market comes up in that context, as I have explained elsewhere. ${ }^{216}$ The usual framework for analyzing accommodation requirements focuses on a single employment market depicted by a single supply and demand diagram, just as in Figure ${ }^{2} .^{217}$ But with accommodation requirements it is important to consider two distinct markets: the market for employees accommodated by the legal intervention and the market for the remaining employees. ${ }^{218}$ The reason is that each market will have its own labor supply and demand curves (although in certain contexts the demand curves will end up being the same). ${ }^{219}$ And, because the demand for one type of employee will depend, among other things, on the demand for employees of the other type, it is no longer "possible to represent everything of interest on a single, twodimensional supply and demand diagram" like Figure $I^{220}$ The development of a more complete framework is the main methodological innovation of my prior work on accommodation requirements, and, as explained below, exactly the same insights apply to antidiscrimination law.

2. Analyzing Antidiscrimination Law. - This section explains how the framework developed for accommodation requirements applies to prohibitions on intentional discrimination. It also briefly notes the framework's (obvious) application to aspects of antidiscrimination law that, as discussed in Part II above, are in fact accommodation requirements. Throughout the discussion to follow, I refer to the group of employees targeted by the legal intervention (for instance, female employees in the case of laws against sex discrimination) as the "disadvantaged" employees and to the remaining employees as the "nondisadvantaged" group.

(a) Prohibitions on Intentional Discrimination. - Prohibitions on intentional discrimination obviously cover differential wages and employment levels between groups, but they also apply to differential treatment in terms of conditions on the job - for instance, the workplace environment. ${ }^{221}$ Restrictions on differential job conditions will produce supply and demand effects parallel to those of accommodation requirements because, just like accommodation requirements, such restrictions will make disadvantaged employees more willing to supply

\footnotetext{
216 Jolls, supra note $2 \mathrm{r} 2$, at $240-41$.

217 See id. at 226 \& n.9.

218 Id. at 240 .

219 Id.

$220 I d$.

221 See, e.g., Harris v. Forklift Sys., Inc., 5 10 U.S. I7, 2 I-2 2 (1993) (workplace environment under Title VII); Annis v. County of Westchester, 36 F.3d 25I, 254 (2d Cir. 1994) (workplace environment under the Equal Protection Clause).
} 
labor while increasing employers' costs of employing these employees. The following paragraphs elaborate upon these points.

Consider first labor supply. How will members of the disadvantaged group respond to restrictions on sexual harassment and other differential job conditions? They are likely to be more willing to supply labor at any given wage with such restrictions in place, as Donohue and Vicki Schultz, among others, have noted. ${ }^{222}$ In this respect restrictions on differential job conditions are just like accommodation requirements, for just as disadvantaged employees will be more willing to supply labor at any given wage once a particular benefit must be provided to them, ${ }^{223}$ they will be more willing to supply labor at any given wage once the workplace is free of differential job conditions.

Effects parallel to those of accommodation requirements also occur for labor demand. Restrictions on differential job conditions impose costs on employers, just as do accommodation requirements; with such restrictions in place, employers are subject to a potential lawsuit over every adverse incident on the job suffered by a disadvantaged employee. These costs shift down the marginal revenue product of labor for disadvantaged employees, just as the costs associated with accommodation requirements shift down this marginal revenue product of labor. ${ }^{224}$

Consider the example of sexual harassment. Without offering a complete analysis of that topic insofar as the productivity effects on employers are concerned, it seems clear that introducing a law against such harassment into a male-dominated workplace characterized by anti-female behavior toward the small number of women in that workplace will create real costs for the employer in the form of exposure to sexual harassment liability - much as various kinds of accommodation requirements will create real costs for the employer. Notice that, just as in the case of accommodation requirements, the costs here are ones created by the legal regime. The significance of this point is that even if discriminatory conditions (such as differences in educational quality) and discriminatory attitudes go away with time, as presumably is contemplated by antidiscrimination law, ${ }^{225}$ the law will still impose costs in connection with the restrictions it places on

222 John J. Donohue III, Prohibiting Sex Discrimination in the Workplace: An Economic Perspective, 56 U. CHI. L. REV. 1337, 1349 (1989); Vicki Schultz, Telling Stories About Women and Work: Judicial Interpretations of Sex Segregation in the Workplace in Title VII Cases Raising the Lack of Interest Argument, 103 HARV. L. REV. 1749, 1815-39 (1990).

223 Jolls, supra note 212 , at $24 \mathrm{I}-42$.

224 See id. at 240.

225 See, e.g., Cass R. Sunstein, Legal Interference with Private Preferences, 53 U. CHI. L. REV. II29, II 54-55 (1986). 
differential job conditions because the very ability to sue an employer over an employment decision imposes costs even if the decision was made wholly free of any discriminatory influence. ${ }^{226}$

In the existing literature, the notion that prohibitions on intentional discrimination impose costs on employers in connection with employing disadvantaged employees comes up mainly in discussions of "firing costs"; the idea is that antidiscrimination law makes it difficult to fire disadvantaged employees and thus increases the cost of employing such employees. ${ }^{227}$ But this form of cost increase is distinct in important ways from the cost increase stemming from restrictions on differential conditions while on the job, for the latter cost increase, like the cost increase from a required accommodation, is not directly linked to the employment level (although it will indirectly affect it through the shifts in labor supply and marginal revenue product of labor it will produce). In the firing costs story, the legal intervention is directly linked to the employment level. Because it is not possible in general to determine how the competing effects on employment level in the firing costs story - a potential increase in disadvantaged employees' employment because of the barriers to firing, but a potential decrease in their employment because of the reduced incentive to hire - balance out, ${ }^{228}$ I do not attempt to incorporate the firing costs idea into my analysis here.

As the discussion above suggests, it is important in general to distinguish between the limits on employment differentials imposed by antidiscrimination law, on the one hand, and the restrictions on differential job conditions imposed by this law, on the other. Within the supply and demand framework used here, restrictions on differential job conditions can be reflected in supply and marginal revenue product of labor shifts, just as accommodation requirements can be reflected in such shifts. In both cases, the effect of the legal intervention is to change the willingness of disadvantaged employees to supply labor and the marginal revenue product of those employees' labor. Lim-

226 Cf. Richard A. Epstein, In Defense of the Contract at Will, 5 I U. CHI. L. REV. 947, 970 (1984) (noting that a general "for-cause" standard for discharging employees will impose process costs even on employers who obey the substantive standard).

227 E.g., Donohue \& Siegelman, supra note I42, at 1024; Richard A. Posner, The Efficiency and Efficacy of Title VII, 136 U. PA. L. REV. 513,519 (1987).

228 See Francine D. Blau \& Lawrence M. Kahn, Institutions and Laws in the Labor Market, in 3A HANDBOOK OF LABOR ECONOMICS I399, I4I2-I3 (Orley Ashenfelter \& David Card eds., 1999) (describing how "the impact of firing costs ... depends on the shape of the marginal [revenue] product of labor (MRPL) curve and on the presence of discounting and voluntary turnover," and considering several alternative scenarios); see also Daron Acemoglu \& Joshua D. Angrist, Consequences of Employment Protection? The Case of the Americans with Disabilities Act, 109 J. POL. ECON. 915, 92 I-24 (2001) (modeling the competing effects of firing costs and hiring incentives). 
its on employment differentials, by contrast, cannot be analyzed in this way; because employment level is one of the axes of the supply and demand framework, the effects of limits on employment differentials obviously cannot be analyzed in terms of shifts in the supply and marginal revenue product of labor curves. ${ }^{229}$

(b) Aspects of Antidiscrimination Law That Are in Fact Accommodation Requirements. - The foregoing discussion bears straightforwardly on the analysis of those aspects of antidiscrimination law that are in fact accommodation requirements. Insofar as it is job conditions that are being regulated by these aspects of antidiscrimination law, it is obvious that, as these aspects are identical to accommodation requirements, the supply and demand analysis of accommodation requirements applies. By contrast, insofar as it is hiring practices (for instance, the use of general ability tests) that are being regulated, the legal intervention relates directly to the employment level and thus cannot be immediately incorporated into the framework offered above. ${ }^{230}$

3. Effects of Antidiscrimination Law. - My earlier work describes at some length the wage and employment effects of accommodation requirements, ${ }^{231}$ and, for the reasons just given, this analysis translates directly to the present context of the restrictions on differential job conditions imposed by prohibitions on intentional discrimination and other aspects of antidiscrimination law. One conclusion from the earlier analysis warrants specific mention here, however, because of the difference between this conclusion and the usual view in the existing literature on the effects of antidiscrimination law.

Within the supply and demand framework set forth above, the basic factor that drives the wage and employment effects of accommodation requirements and the restrictions on differential job conditions imposed by antidiscrimination law is the degree to which there are binding limits on wage and employment differentials between disadvantaged and nondisadvantaged employees. ${ }^{232}$ This is so because the degree to which there are such binding limits determines the degree to

229 Another assumption of the framework used here is that at least some of the costs created by the legal intervention are ones that rise with the employment level of the disadvantaged group; the costs are not exclusively fixed or up-front costs. Jolls, supra note 212 , at 235 . Thus, for example, if the employment of one female employee means that an employer will institute an extensive sexual harassment training program that will stamp out all risk of harassment, then there may be no cost associated with employing additional female employees, and the framework described here would not directly apply. For additional assumptions of the framework, see id. at $238-40$.

230 See John J. Donohue III, Understanding the Reasons for and Impact of Legislatively Mandated Benefits for Selected Workers, 53 STAN. L. REV. 897, 905-06 (2001).

231 Jolls, supra note 2 I 2 , at 242-61.

232 See id. 
which the costs created by accommodation requirements and restrictions on differential job conditions will be borne by disadvantaged employees as opposed to being shared - as a consequence of binding limits on wage and employment differentials - across all employees.

The result I wish to highlight here involves the case in which limits on both wage and employment differentials are fully binding on employers. In this case, antidiscrimination law's restrictions on differential job conditions - like requirements of accommodation - ordinarily will make disadvantaged employees better off because the costs of the intervention will be partially shifted to nondisadvantaged employees. ${ }^{233}$ This outcome, of course, is not surprising and is presumably the point of the intervention. However, the interesting result I wish to emphasize here is that in certain cases the restrictions on differential job conditions imposed by antidiscrimination law will actually make disadvantaged employees worse off, even though limits on wage and employment differentials between disadvantaged and nondisadvantaged groups are fully binding. ${ }^{234}$ This will occur if the disadvantaged group comprises a large fraction of the relevant labor pool and the cost of the legal intervention to employers exceeds its value to disadvantaged employees by a sufficient margin. ${ }^{235}$ The intuition here is that if the disadvantaged group comprises a large fraction of the relevant labor pool, then there is not a large group of nondisadvantaged employees to help share the costs of the legal intervention. With such limited prospects for cost-shifting, and with costs of the intervention in excess of the value of the intervention to the disadvantaged group, the disadvantaged group can be made worse off by the legal intervention even though limits on wage and employment differentials are fully binding. ${ }^{236}$

The possibility that antidiscrimination law's restrictions on differential job conditions may make disadvantaged employees worse off even with fully binding limits on wage and employment differentials has been completely overlooked in the existing literature. In the literature the claim that antidiscrimination law may hurt disadvantaged employees is linked to the idea that limits on wage and employment differentials - and in particular limits on hiring differentials - may not be binding; therefore the costs associated with antidiscrimination law may make it harder for disadvantaged employees to get jobs in the first place. ${ }^{237}$ But when the problem is analyzed in a more systematic

\footnotetext{
233 See id. at 246-51.

234 Id. at 249.

235 See id. at 249-50.

236 See id.

237 See, e.g., Acemoglu \& Angrist, supra note 228, at 923; Donohue \& Siegelman, supra note 142, at 1024; Scott A. Moss \& Daniel A. Malin, Public Funding for Disability Accommodations: $A$
} 
way, as it may be with the supply and demand framework described here, it becomes clear that disadvantaged employees may be harmed by antidiscrimination law even if limits on wage and employment differentials are fully binding.

An application of this idea is to restrictions on male-female differentials in job conditions. Because women comprise such a large fraction of the relevant labor pool for certain occupations (such as child care workers and receptionists ${ }^{238}$ ), prospects for cost-shifting in these sectors are limited, and therefore restrictions on differential job conditions may make female employees worse off unless the value of these restrictions to such employees is near or equal to their cost to employers. Thus, for instance, if the value of a particular form of health insurance coverage specific to women (say, coverage of prescription contraceptives) is less than the cost of such coverage, then requiring such coverage under antidiscrimination law may make female employees worse off in segregated job categories.

\section{Beyond Cost}

The analysis just offered suggests the ways in which prohibitions on intentional discrimination and requirements of accommodation are broadly similar from the perspective of their wage and employment effects on disadvantaged and nondisadvantaged employees. While it is fairly obvious that prohibitions on discrimination based upon customer or coworker attitudes, as well as prohibitions on rational statistical discrimination, force employers to bear costs, as described in section III.A above, the analysis just given shows that in fact prohibitions on intentional discrimination in general impose costs on employers. These cost arguments supplement other non-cost reasons for regarding prohibitions on intentional discrimination and requirements of accommodation as similar rather than fundamentally distinct. These other reasons are briefly noted here.

One familiar reason for the view that prohibitions on intentional discrimination and requirements of accommodation are similar rather than distinct is the notion that it is the interaction of a number of factors, some of them socially constructed rather than "natural," that produces a need for distinctive treatment of one group of employees, and thus (according to this argument) it is as much the case that the socially constructed factors are "discriminatory" as it is that the "natural" factors require accommodation. For instance, a person in a wheelchair

Rational Solution to Rational Discrimination and the Disabilities of the ADA, 33 HARV. C.R.C.L. L. REV. 197,2 I 7-18 (1998).

238 See Francine D. Blau, Patricia Simpson \& Deborah Anderson, Continuing Progress? Trends in Occupational Segregation in the United States over the I970s and 1980s, 4 FEMINIST ECON. 29, 65, 66 (1998). 
does not require accommodation simply because of the "natural" condition of being in a wheelchair in isolation; rather the problem arises because of the interaction between being in a wheelchair and living in a world in which architects and builders choose to produce structures with doors of a certain size, raised doorsteps, and so forth - choices that some suggest are "discriminatory."239 Similarly, a pregnant employee may require distinctive treatment not because of the pregnancy considered in isolation, but because of the interaction between pregnancy and various work structures, such as employer attendance policies that do not provide time off for temporary disability. ${ }^{240}$ As Martha Minow notes, to characterize leave or other benefits for pregnancy as "special" rather than "equal" treatment reflects a norm of "a workplace designed for men." 241

A related argument is that in some circumstances the failure to accommodate amounts to acceptance of clearly unequal access, and this in turn may be "discriminatory." Herma Hill Kay's discussion of pregnancy provides an example. "[E]quality of opportunity," she writes, "implies that [a] woman should not be disadvantaged as a result of that sex-specific variation [whereby women but not men bear children]."242 "Since the man will not be disabled from work as the result of [having children], equal protection for the woman," (or, equivalently, nondiscrimination against her) "requires that she not be penalized if she does become disabled." 243 Thus, nondiscrimination may require such "accommodationist" steps as the provision of particular benefits to pregnant employees. ${ }^{244}$

In terms of the broader academic debate, once we start to see prohibitions on intentional discrimination in terms of "antisubordination" rather than merely in terms of forbidding "irrational" distinctions between like candidates, ${ }^{245}$ the idea of an important gap between such prohibitions and requirements of accommodation goes away. From an antisubordination perspective, prohibitions on intentional discrimination, like requirements of accommodation, are fundamentally concerned with the elimination of group subordination, not with requiring

239 E.g., Ruth Colker, The Section Five Quagmire, 47 UCLA L. REV. 653, 699 n.209 (2000); Matthew Diller, Judicial Backlash, the ADA, and the Civil Rights Model, 2 I BERKELEY J. EMPL. \& LAB. L. 19, 4I-43 (2000); Sunstein, supra note 18, at 35 .

240 See, e.g., Finley, supra note 90, at II52-59; Christine A. Littleton, Reconstructing Sexual Equality, 75 CAL. L. REV. I 279, I306-07 (1987).

241 Minow, supra note 18 , at $4 \mathrm{I}$.

242 Kay, supra note 15 , at 26.

243 Id. at $3 \mathrm{I}$.

244 Id.

245 See, e.g., Bagenstos, supra note 17 , at 456-57. 
treatment of individuals purely in accordance with their personal merit or productivity. ${ }^{246}$

\section{AfFirmative ACTION}

How does affirmative action fit into the discussion here of the relationship between antidiscrimination and accommodation? The question of how affirmative action and accommodation are and are not similar to one another, and the implications of the comparison for the relationship between affirmative action and antidiscrimination, are fascinating topics, which others have engaged in some detail. ${ }^{247} \mathrm{My}$ purpose is not to offer anything even approaching a comprehensive discussion of the issues, but at least a few points seem worth noting very briefly.

First, it is clear that accommodation, while similar to affirmative action in some ways, is also distinct in a number of important respects - including in the respect that affirmative action seems to focus on disadvantage that is at its foundation "social" rather than "biological" or "natural" (although, as noted just above, the divide between "social" and "natural" grounds for disadvantage is slippery ${ }^{248}$ ). This focus of affirmative action creates a very real possibility of stigma to a degree that may not be present in the accommodation context.

Second, accommodation may also be distinct from affirmative action in the sense that the latter seems more clearly than the former to contemplate the possibility of disrupting discrete interests of identifiable fellow employees. In the accommodation context, a frequent refrain of courts is that the "reasonable accommodations" mandate of the Americans with Disabilities Act does not "requir[e] affirmative action" precisely because it does not force the employer to disrupt such interests of identifiable employees ${ }^{249}$ (although, like any added cost of doing business, it may depress the general level of employment and thus affect employees as a group). This conception of the ADA is likely to be tested in the Supreme Court this Term in its review of a Ninth Circuit decision requiring, in contrast with the approach of most courts, disruption of identifiable employees' interests as a component of providing the "reasonable accommodations" mandated by the ADA. ${ }^{250}$

246 See id. at $455-58$.

247 E.g., Karlan \& Rutherglen, supra note I6, at 14-22, 38-4I; Jerry L. Mashaw, Against First Principles, 3 I SAN DIEgo L. REV. 2 I I, 2 I 7-18 (I 994).

248 See supra notes $239-24 I$ and accompanying text.

249 See, e.g., Daugherty v. City of El Paso, 56 F.3d 695, 698-700 (5th Cir. I995); EEOC v. Sara Lee Corp., 237 F.3d 349, 353-54 (4th Cir. 200I) (quoting Daugherty, 56 F.3d at 700).

250 US Airways, Inc. v. Barnett, 228 F.3d II05, II I 7-20 (9th Cir. 2000), cert. granted, i 2 I S. Ct. 1600 (2001). 
Third, and most connected to the points emphasized in this work, while accommodation does seem different from affirmative action in various respects, both it and antidiscrimination are similar to affirmative action in the respect that all three forms of intervention require employers to bear undeniable financial costs associated with a particular group of employees, and in that sense to "accommodate" these employees. Just as there is no sharp line between antidiscrimination and accommodation in this regard, there is similarly no sharp line between antidiscrimination and affirmative action. My argument here is akin to David Strauss's suggestion that prohibitions on various forms of intentional discrimination share much in common with affirmative action. ${ }^{251}$

\section{CONCLUSION}

The question of the relationship between antidiscrimination and accommodation is an old and venerable one. I have attempted to shed new light on it in two specific respects. First, I have argued that certain aspects of antidiscrimination law, in particular its disparate impact branch, are in fact accommodation requirements. This claim is not a normative one; it is simply that the two categories overlap as a factual matter. It follows from this argument that if disparate impact liability is within Congress's power under Section 5 of the Fourteenth Amendment - as courts thus far have held it is - then the same conclusion should follow for legal rules, such as the Family and Medical Leave Act, that expressly mandate the provision of particular benefits to employees, but that have a substantive scope similar to that of applications of disparate impact liability.

The second point developed above is that even those aspects of antidiscrimination law that prohibit intentional discrimination, and thus do not directly qualify as accommodation requirements, nonetheless share important and previously unrecognized parallels with such requirements. As described above, prohibitions on intentional discrimination require employers to bear real financial costs associated with a particular group of employees, and in this respect to "accommodate" those employees. The wage and employment effects of prohibitions on intentional discrimination, insofar as those prohibitions regulate conditions on the job, are parallel to those of accommodation requirements.

A next step in utilizing the framework of wage and employment effects described in the second part of my analysis would be to test the analytic predictions generated by the framework against the existing 
empirical data. There is a vast body of empirical work on the wage and employment effects of laws prohibiting discrimination on the basis of race and sex. ${ }^{252}$ Prior work in the context of express mandates of particular employment benefits, as under the Family and Medical Leave Act and the Americans with Disabilities Act, suggests a good fit between the analytic framework and the data. ${ }^{253}$ A next step is to see if the same is true for antidiscrimination law.

252 For a recent summary, see DAVID NEUMARK \& WENDY A. STOCK, THE EFFECTS OF RACE AND SEX DisCRIMINATION LAWS $3-9$ (Nat'l Bureau of Econ. Research, Working Paper No. 8215,2000$)$.

253 Jolls, supra note 2 I 2 , at $272-300$. 


\section{$\mathrm{H}$ $A$ $\mathrm{R}$ $\mathrm{V}$ A $\mathrm{R}$ D L A W $\mathrm{R}$ E V IE W}

CHRISTOPHER ANDERSON COLETTE PARRIS BATISTE DAVID BITKOWER JONATHAN H. BLAVIN F. TURNER BUFORD III JENNTFER BURRELL SUSAN A. CHEN ANNE B. Clamborne LISA M. COAR I. GLENN COHEN MatTHEW Colangelo JENNY ANN DLAMOND JUSTIN DILLON NORINA EDELMAN JOSHUA FELTMAN LAUREN B. Fletcher JAMES O. FREEMAN MARK R. FREEMAN JEANNE C. FROMER DANIEL L. GEYSER CLIFFORD M. GINN YARON Y. GLAZER EMILY R. GOLD DANIEL L. GOLDBERG MICHAEL J. GOTTLIEB Danielle C. Gray TARA LEIGH GROVE ALMA HADAR LATONIA H. HANEY

Colleen Verner Circulation Director
BenJaMin L. HaTCH JAMES G. HEIN, JR. MATTHEW S. HELLMAN JENNIFER A. HICKEY BERT I. HUANG ANDREW S. JACOBS RAJESH S. JAMES KELLY M. JASKE BENJAMIN J. KEITH ELIZABETH KENNEDY TARA KOLE Christos J. Kolovos DAVID S. KURTZER DOMINIC LANZA JUSTIN D. LERER JEFFREY H. LERNER JUSTIN LEVTTT RITA LIN GREGORY M. LIPPER MARY CATHERINE MARTIN SARAH MCGONIGLE GARRETT MORITZ NATHAN OMAN REBECCA D. ONIE JAMES J. PRESCOTT AI.ISHA QUINTANA ANA RAQUEL RAFFALS ADAM RAVIV EZRA W. REESE
EDNA RIENZI

DANIELLE E. ROLFES

RAHSAAN J. SALES

MARK E. SCHNEDER

DANIEL B. SCHWARCZ

MICHAEL SCOVILLE

Michael K. ShaH

JEREMY SHEFF

TERI-ANN SHIROMA

REBECCA J. SILVERSTEIN

LEIF T. SIMONSON

SUZETTE A. SMIKLE

JOSHUA SOLOMON

RENEE SOTO

BENJAMIN SOUEDE

MATTHEW STEPHENSON

DAVD M. STETSON

JEANNIE SUK

ALLISON BROWNELL TIRRES

LOUIS W. TOMPROS

D. HIEN TRAN

DANIEL S. VOLCHOK

ALEXANDER VOLOKH

KEVIN CHRISTIAN WALSH

DAVIS WANG

HENRY WHTTAKER

LINDSAY F. WILEY

SCOTT WHKENS

ROBYN E. ZOLMAN

Published eight times during the academic year by Harvard law students.

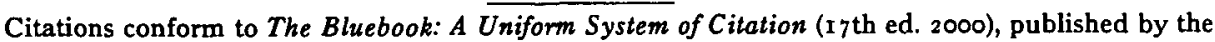
Harvard Law Review Association for the Columbia Law Review, the Harvard Law Review, the University of Pennsylvania Law Review, and The Yale Law Journal. 